\title{
A Network Pharmacology-Based Approach to Explore Therapeutic Mechanism of Indian Herbal Formulation Nisha Amalaki in Treating Type 2 Diabetes Mellitus
}

\section{Mohit Wadhawan}

All India Institute of Medical Sciences (AlIMS)

Varun Chhabra

All India Institute of Medical Sciences (AlIMS)

Amit Katiyar

All India Institute of Medical Sciences (AIIMS)

Vandna Sharma

All India Institute of Medical Sciences (AIIMS)

\section{Bharat Krushna Khuntia}

All India Institute of Medical Sciences (AlIMS)

\section{Shubhangi Rathore}

All India Institute of Medical Sciences (AlIMS)

\section{Punit Kaur}

All India Institute of Medical Sciences (AlIMS)

Gautam Sharma ( $\nabla$ drgautamsharma12@gmail.com )

All India Institute of Medical Sciences (AlIMS)

\section{Research Article}

Keywords: herbal, diabetes, phytochemicals, metabolite, proliferation

Posted Date: October 13th, 2021

DOI: https://doi.org/10.21203/rs.3.rs-954990/v1

License: (c) (i) This work is licensed under a Creative Commons Attribution 4.0 International License. Read Full License 


\section{Abstract}

Nisha Amalaki (NA), an Indian herbal formulation consisting of two herbs, Curcuma longa and Emblica officinalis, has been commonly used to treat Type 2 diabetes mellitus (T2DM). However, the pharmacological mechanism of NA remains unknown. In this study, a network pharmacology-based approach was used to explore its underlying mechanism. NA phytochemicals were collected from PubChem, KNApSAcK, IMPPAT, and ChEBI databases, and their potential targets were investigated using similarity ensemble approach (Tanimoto coefficient $\geq 0.6$ ). A protein-protein interaction network was constructed to study the interactions among the targets and clustered into separate modules using NetworkAnalyst 3.0. A significant module $(P \leq .01)$ was identified, and DAVID web tool was utilized for the enrichment analysis. A total of 201 phytochemicals and 262 targets of NA were selected. Forty-five nodes of the significant module were identified as potential targets of NA. The enrichment analysis exhibited 27 biological processes and 78 pathways $(P \leq .01)$. Out of 45,18 nodes were associated with T2DM as probable targets of NA. The metabolite-target-pathway network revealed that anti-diabetic effect of NA is a synergy of multi-target and multi-pathway efforts via regulation of glucose, lipid metabolism, insulin resistance, $\beta$-cell survival and proliferation, inflammation, apoptosis, and cell cycle.

\section{Introduction}

Diabetes mellitus (DM) is a chronic, complex metabolic disorder, and the most common form is Type 2 diabetes mellitus (T2DM) ${ }^{1}$. It is estimated to affect approximately 422 million people worldwide, resulting in 1.6 million deaths annually ${ }^{2}$. Conventional therapies used to treat diabetes may be promising in glycemic control but are reported to have potential side effects like hypoglycemia, vitamin B12 deficiency, pancreatitis, upper RTI infection, lipoatrophy, weight gain, and gastrointestinal dysfunction ${ }^{3,4}$. Consequently, people are turning their attention to traditional herbal medicine or diet-based therapy as a safer and more cost-efficient alternative medicine for T2DM ${ }^{5-7}$.

Indian traditional medicinal system is a rich resource that describes various Indian medicinal plants used to prevent and treat T2DM 8,9 . Nisha Amalaki (NA), an Ayurvedic herbal formulation, has been used in the traditional Indian medicinal system to treat T2DM ${ }^{10,11}$. It consists of a fine powder of turmeric rhizomes (Curcuma longa L.; Nisha, Haridra in Sanskrit; Family: Zingiberaceae; $\mathrm{CL}$ ) and Indian gooseberry (Emblica officinalis L.; Amalaki in Sanskrit; Family: Euphorbeaceae; EO), prepared as a 1:1 (w/w) mixture ${ }^{12}$. Both $\mathrm{CL}$ and $\mathrm{EO}$ are known for diverse medicinal properties. $C$. Ionga is a common Indian spice traditionally used to treat several ailments such as diabetes, rheumatism, cancer, urinary disease, liver disorders, inflammation, cough, wound, and bruise healing ${ }^{13}$. Curcumin and its derivatives, such as bisdemethoxycurcumin and desmethoxycurcumin, are major phytochemicals in $C$. longa. They have been reported to possess significant antioxidant, anti-inflammatory, anti-infective, anti-carcinogenic, anticoagulant, and anti-diabetic activity ${ }^{14-17}$. On the other hand, $E$. officinalis contains phytochemicals such as pedunculagin, gallic acid, emblicanin, quercetin, chebulinic acid, and corilagin, which has been shown to have antioxidant, anticancer, anti-inflammatory, anti-diabetic, antimicrobial, adaptogenic, nootropic, 
and immunomodulatory potential ${ }^{18,19}$. It has also been reported to prevent hyperlipidemia, osteoporosis, and several other ailments ${ }^{20}$. Although both the herbs possess anti-diabetic activity, the pharmacological action of the NA formulation remains to be explored. Both herbs and their formulation, NA, have been implicated in the treatment of diabetes, but their underlying mechanism of action is still not clear.

Network pharmacology (NP) approach has been a promising for understanding traditional herbal formulas ${ }^{21}$, identifying probable new drugs or targets ${ }^{22-24}$, and provide novel insights into drug actions. In addition, it explores potential target spaces by allowing an unbiased examination of current drug molecules used in various therapeutic conditions ${ }^{25}$. It elucidates the probable mechanism of action of phytochemicals/bio-active compounds through huge dataset analysis and determines their synergistic effects in treating complex diseases ${ }^{26}$.

Therefore, this study was designed to develop an NP-based method to identify possible therapeutic targets and explore the underlying mechanism of this herbal formulation. First, the protein-protein interaction (PPI) network was generated using putative targets of phytochemicals from NA. Next, the network was clustered into various modules containing targets sharing a functional similarity. Finally, the modules with significant $P$-value were identified and enriched to pathways to generate the metabolitetarget-pathway interaction network. Also, the gene-disease association network was created to explore the use of NA in other diseases. The workflow of the NP-based method for NA herbal formulation has been shown in Figure 1.

\section{Results}

NA phytochemicals and target prediction. A total of 201 phytochemicals identified in NA (108 in CL and 93 in EO) were collected with CAS ID (Chemical Abstracts Service registry number) and PubChem CID (Supplementary file 1). The possible targets of the NA phytochemicals were determined using similarity ensemble approach (SEA). The scope of potential targets of NA was narrowed from 5187 to 1052 based on the Tanimoto Coefficient (Tc max $\geq 0.6$ ) (Supplementary file 2). Further duplicate entries and genes not found in humans were removed, and the number of targets for analysis gradually decreased from 1052 to 262 .

PPI network analysis and module identification. The PPI network was created using NetworkAnalyst 3.0 as an undirected network, i.e., edges having no direction. The target genes/proteins were represented as 'nodes,' and the interaction between any two genes/proteins was represented by 'edge.' The network analysis revealed the interaction of 163 nodes via 604 edges (Figure 2). In the network, 42 nodes showed a degree of one, while 121 nodes showed a degree more than one. Out of 121 nodes, 39 nodes had $\geq$ ten connections to other nodes. We also found "betweenness" ranging from 2.5 to 2617.62 for 94 nodes in the constructed network. The results indicate that the constructed network was abundant in the hub proteins (high degree, i.e., number of connections with other nodes) and bottleneck proteins (high betweenness, i.e., number of shortest routes passing through a node), which suggests that they may be important proteins ${ }^{27,28}$. Based on the results, proteins having the high degree in the PPI network showed 
the high betweenness. As hub proteins contribute to many interactions and hold the network together ${ }^{29}$, they play a crucial role in regulating signaling pathways as well as transcription. Therefore, hub proteins may serve as potential therapeutic targets or biomarkers.

The constructed PPI network was further clustered into modules, which contain proteins with similar functions. A network module is a subnetwork in which nodes are more closely linked to each other than rest of the network. Identifying the modules within the network is important as it might help in detecting the hidden structural information. Seven highly connected independent modules were observed, out of which only Module 1 showed a significant $P$-value $(P \leq .001)$ (Table 1$)$. Thus, the PPI network of Module 1 was extracted for further analysis (Figure 3 ). The particulars of topological parameters, i.e., closeness centrality, betweenness centrality, eccentricity, and degree, have been shown in Table 2, highlighting the importance of each target in the network.

Table 1

Identification of modules of the PPI network

\begin{tabular}{|c|c|c|c|}
\hline Modules & Targets & Size & $P$-value \\
\hline $\begin{array}{l}\text { Module } \\
1\end{array}$ & $\begin{array}{l}\text { AKT1, AURKA, AURKB, BCL2, CCND1, CRYAB, CSNK2A1, CYP19A1, } \\
\text { DNMT1, EP300, ESR1, ESR2, FABP3, FOS, GSK3B, HDAC1, HDAC2, } \\
\text { HDAC3, HDAC8, HDAC9, IL2, JUN, KDM2A, MAP3K8, MCL1, MMP1, } \\
\text { MMP13, MMP2, MMP9, NFE2L2, NFKB1, NR3C1, NR4A1, PLK1, } \\
\text { PLK4, PPARD, PPARG, RELA, RXRA, SMAD3, SRC, SREBF2, TERT, } \\
\text { TOP1, TOP2A }\end{array}$ & 45 & 0.0000291 \\
\hline $\begin{array}{l}\text { Module } \\
2\end{array}$ & $\begin{array}{l}\text { ALK, AXL, EGFR, ERBB2, FYN, IGF1R, INSR, MET, MYLK, PDGFRB, } \\
\text { PIK3R1, PTK2, PTPN1, PTPN2, PTPN6, STAT1, STAT3, SYN1, TLR2 }\end{array}$ & 19 & 0.303 \\
\hline $\begin{array}{l}\text { Module } \\
3\end{array}$ & $\begin{array}{l}\text { ABCB1, ABCG2, ACHE, ALOX5, APEX1, APP, CCNA1, CCNA2, CDK1, } \\
\text { CDK4, DYRK1A, ELAVL1, EPHB4, NOS3, NÚAK1, PIM1, VCP }\end{array}$ & 17 & 0.889 \\
\hline $\begin{array}{l}\text { Module } \\
4\end{array}$ & $\begin{array}{l}\text { ABCB11, CYP3A4, NR1H2, NR1H3, NR1H4, PPARA, RARB, RARG, } \\
\text { RXRB, RXRG, SPHK1 }\end{array}$ & 11 & 0.789 \\
\hline $\begin{array}{l}\text { Module } \\
5\end{array}$ & ACP1, DAPK1, FASN, FLT3, FLT4, IKBKG, KDR, TEK, TPT1 & 9 & 0.476 \\
\hline $\begin{array}{l}\text { Module } \\
6\end{array}$ & HDAC6, MAPK14, MAPT, PKN1, RPS6KA3 & 5 & 0.67 \\
\hline $\begin{array}{l}\text { Module } \\
7\end{array}$ & CDK2, MIF, MPG, P4HB, PGD & 5 & 1 \\
\hline
\end{tabular}


Table 2

Properties of network Module 1

\begin{tabular}{|c|c|c|c|c|c|c|}
\hline Name & $\begin{array}{l}\text { Betweenness } \\
\text { Centrality }\end{array}$ & $\begin{array}{l}\text { Closeness } \\
\text { Centrality }\end{array}$ & Eccentricity & $\begin{array}{l}\text { Clustering } \\
\text { Coefficient }\end{array}$ & Degree & $\begin{array}{l}\text { Topological } \\
\text { Coefficient }\end{array}$ \\
\hline AKT1 & 0.019 & 0.537 & 3 & 0.378 & 10 & 0.313 \\
\hline AURKA & 0.006 & 0.458 & 3 & 0.400 & 5 & 0.447 \\
\hline AURKB & 0.001 & 0.419 & 4 & 0.000 & 2 & 0.604 \\
\hline BCL2 & 0.012 & 0.440 & 3 & 0.167 & 4 & 0.346 \\
\hline CCND1 & 0.011 & 0.550 & 3 & 0.667 & 10 & 0.424 \\
\hline CRYAB & 0.003 & 0.440 & 3 & 0.333 & 3 & 0.452 \\
\hline CSNK2A1 & 0.021 & 0.543 & 3 & 0.422 & 10 & 0.366 \\
\hline CYP19A1 & 0.000 & 0.415 & 4 & 1.000 & 2 & 0.780 \\
\hline DNMT1 & 0.003 & 0.478 & 3 & 0.400 & 5 & 0.457 \\
\hline EP300 & 0.095 & 0.677 & 2 & 0.391 & 23 & 0.285 \\
\hline ESR1 & 0.068 & 0.629 & 3 & 0.395 & 20 & 0.310 \\
\hline ESR2 & 0.000 & 0.454 & 3 & 0.900 & 5 & 0.520 \\
\hline FABP3 & 0.001 & 0.383 & 4 & 0.000 & 2 & 0.563 \\
\hline FOS & 0.060 & 0.603 & 3 & 0.368 & 17 & 0.286 \\
\hline GSK3B & 0.059 & 0.543 & 3 & 0.200 & 11 & 0.282 \\
\hline HDAC1 & 0.151 & 0.688 & 3 & 0.313 & 25 & 0.270 \\
\hline HDAC2 & 0.038 & 0.603 & 3 & 0.417 & 16 & 0.313 \\
\hline HDAC3 & 0.052 & 0.620 & 3 & 0.399 & 18 & 0.298 \\
\hline HDAC8 & 0.008 & 0.444 & 3 & 0.200 & 6 & 0.313 \\
\hline HDAC9 & 0.010 & 0.512 & 3 & 0.476 & 7 & 0.377 \\
\hline IL2 & 0.000 & 0.506 & 3 & 1.000 & 5 & 0.545 \\
\hline JUN & 0.125 & 0.657 & 3 & 0.329 & 22 & 0.268 \\
\hline KDM2A & 0.000 & 0.444 & 3 & 1.000 & 3 & 0.611 \\
\hline MAP3K8 & 0.000 & 0.427 & 3 & 0.333 & 3 & 0.600 \\
\hline MCL1 & 0.002 & 0.376 & 4 & 0.000 & 2 & 0.500 \\
\hline MMP1 & 0.000 & 0.449 & 3 & 0.833 & 4 & 0.558 \\
\hline
\end{tabular}




\begin{tabular}{|lllllll|}
\hline Name & $\begin{array}{l}\text { Betweenness } \\
\text { Centrality }\end{array}$ & $\begin{array}{l}\text { Closeness } \\
\text { Centrality }\end{array}$ & Eccentricity & $\begin{array}{l}\text { Clustering } \\
\text { Coefficient }\end{array}$ & Degree & $\begin{array}{l}\text { Topological } \\
\text { Coefficient }\end{array}$ \\
\hline MMP13 & 0.000 & 0.449 & 3 & 0.833 & 4 & 0.558 \\
\hline MMP2 & 0.000 & 0.440 & 4 & 1.000 & 3 & 0.656 \\
\hline MMP9 & 0.000 & 0.500 & 3 & 0.900 & 5 & 0.518 \\
\hline NFE2L2 & 0.000 & 0.423 & 4 & 1.000 & 2 & 0.611 \\
\hline NFKB1 & 0.025 & 0.595 & 2 & 0.505 & 14 & 0.339 \\
\hline NR3C1 & 0.019 & 0.557 & 3 & 0.485 & 12 & 0.360 \\
\hline NR4A1 & 0.032 & 0.512 & 3 & 0.333 & 10 & 0.332 \\
\hline PLK1 & 0.033 & 0.524 & 3 & 0.422 & 10 & 0.370 \\
\hline PLK4 & 0.001 & 0.431 & 4 & 0.333 & 4 & 0.510 \\
\hline PPARD & 0.001 & 0.500 & 3 & 0.786 & 8 & 0.500 \\
\hline PPARG & 0.006 & 0.530 & 3 & 0.639 & 9 & 0.397 \\
\hline RELA & 0.081 & 0.667 & 2 & 0.385 & 22 & 0.285 \\
\hline RXRA & 0.022 & 0.595 & 2 & 0.505 & 14 & 0.331 \\
\hline SMAD3 & 0.053 & 0.603 & 3 & 0.375 & 16 & 0.297 \\
\hline SRC & 0.013 & 0.537 & 3 & 0.439 & 12 & 0.342 \\
\hline SREBF2 & 0.000 & 0.458 & 3 & 0.667 & 4 & 0.516 \\
\hline TERT & 0.000 & 0.484 & 3 & 0.800 & 5 & 0.500 \\
\hline TOP1 & 0.001 & 0.431 & 3 & 0.500 & 4 & 0.433 \\
\hline TOP2A & 0.013 & 0.530 & 3 & 0.429 & 8 & 0.366 \\
\hline
\end{tabular}

Gene ontology (GO) and Kyoto Encyclopedia of Genes and Genomes (KEGG) pathway enrichment analysis. GO enrichment analysis was done on 45 target genes of Module 1, and the GO terms with $P \leq$ .01 were selected and represented on the graph as $-\log P$ values (Figure 4). The results showed that these 45 target genes are involved in various biological processes like negative regulation of apoptotic process, aging, regulation of signal transduction by p53 class mediator, histone $\mathrm{H} 3$ deacetylation, positive regulation of transcription from RNA polymerase II promoter, negative regulation of cell growth, etc. (Figure 4a). In addition, these processes are associated with molecular functions such as transcription factor binding, NF-kappa B binding, protein kinase activity, DNA binding, protein homodimerization activity, etc. (Figure 4b). These processes occur in different cellular components like nucleoplasm, nucleus, cytosol, spindle microtubule, nuclear chromosome, etc. (Figure 4c). 
KEGG pathway enrichment analysis was also done to explore the target's role (Supplementary file 3). The top 30 enriched pathways have been shown in Figure 5. The results showed that the targets were highly enriched in Pathways in cancer, Endocrine resistance, IL-17 signaling pathway, Apoptosis, Cell cycle, Wnt signaling pathway, Longevity regulating pathway- multiple species, etc. In addition, pathways related to the T2DM and its complications were also observed, including, PI3K-Akt signaling pathway, Insulin resistance, TNF signaling pathway, AGE-RAGE signaling pathway in diabetic complications, FoxO signaling pathway, NF-kappa B signaling pathway, Jak-STAT signaling pathway, MAPK signaling pathway, HIF-1 signaling pathway, Non-alcoholic fatty liver disease (NAFLD), etc. These results suggest that NA herbal formulation may exert therapeutic effects by regulating these pathways.

Gene-disease association network. A gene-disease association network constructed for the 45 target genes of Module 1 showed 424 nodes and 611 edges (Figure 6). The degree and betweenness of the resultant diseases ranged from 11 to 1 and 9700.68 to 0 , respectively. The diseases with betweenness $\geq$ 50 were considered significant (Supplementary file 4). The results showed that besides diabetic conditions, NA could be explored in other disease conditions like neoplasms, leukemia, carcinoma, obesity, hypertensive disease, atherosclerosis, osteoporosis, liver cirrhosis, fatigue, heatstroke, depressive and anxiety disorders.

Identification of T2DM genes and corresponding NA phytochemicals. A list of 579 genes related to T2DM was identified using various databases as described in methodology (Supplementary file 5). Out of 45 genes, 18 were common among Module 1 and the T2DM related gene list (Table 3). The NA phytochemicals targeting these 18 gene targets were identified as curcumin, quercetin, (2S)-Eriodictyol 7O-beta-D-glucopyranoside, arachidic acid, bis-(4-hydroxycinnamoyl)methane, bisdemethoxycurcumin, calebin A, demethoxycurcumin, dihydrocurcumin, letestuianin B, corilagin, indole-3-acetic acid, chebulinic acid, tauroursodeoxycholic acid, Go-Y022, epigallocatechin gallate, eriodictyol, glycocholic acid, naringenin, naringenin 7-0-beta-D-glucoside, beta-carotene, and quercetin-3-0-glucoside. The results also showed that AKT1, BCL2, CYP19A1, ESR1, IL2, MCL1, NR4A1, and RXRA are the targets of EO, while EP300, HDAC1, JUN, NFKB1, NR3C1, PPARD, and PPARG are the targets of CL. However, GSK3B, MMP2, and MMP9 are the common targets of both $\mathrm{CL}$ and EO. 
Table 3

Nisha Amalaki gene targets related to Type 2 diabetes mellitus

\begin{tabular}{|c|c|c|c|c|c|}
\hline $\begin{array}{l}\text { Target } \\
\text { gene }\end{array}$ & $\begin{array}{l}\text { Protein } \\
\text { Description }\end{array}$ & $\begin{array}{l}\text { UniProt } \\
\text { ID }\end{array}$ & $\begin{array}{l}\text { Associated } \\
\text { pathways }\end{array}$ & $\begin{array}{l}\text { Relevant } \\
\text { phytochemical(s) }\end{array}$ & Herb \\
\hline \multirow[t]{3}{*}{ AKT1 } & \multirow[t]{3}{*}{$\begin{array}{l}\text { RAC-alpha } \\
\text { serine/threonine- } \\
\text { protein kinase }\end{array}$} & \multirow[t]{3}{*}{ P31749 } & \multirow{3}{*}{$\begin{array}{l}\text { Insulin resistance, } \\
\text { PI3K-Akt signaling } \\
\text { pathway, AGE-RAGE } \\
\text { signaling pathway } \\
\text { in diabetic } \\
\text { complications, } \\
\text { AMPK signaling } \\
\text { pathway, HIF-1 } \\
\text { signaling pathway, } \\
\text { FoxO signaling } \\
\text { pathway, MAPK } \\
\text { signaling pathway, } \\
\text { TNF signaling } \\
\text { pathway }\end{array}$} & Quercetin & EO \\
\hline & & & & & \\
\hline & & & & Ellagic acid & EO \\
\hline BCL2 & $\begin{array}{l}\text { Apoptosis } \\
\text { regulator } \mathrm{Bcl}-2\end{array}$ & P10415 & $\begin{array}{l}\text { Apoptosis, AGE- } \\
\text { RAGE signaling } \\
\text { pathway in diabetic } \\
\text { complications, HIF- } \\
1 \text { signaling } \\
\text { pathway, NF-kappa } \\
\text { B signaling } \\
\text { pathway, PI3K-Akt } \\
\text { signaling pathway, } \\
\text { Jak-STAT signaling } \\
\text { pathway }\end{array}$ & $\begin{array}{l}\text { Epigallocatechin } \\
\text { gallate }\end{array}$ & EO \\
\hline \multirow[t]{4}{*}{ CYP19A1 } & \multirow[t]{4}{*}{ Aromatase } & \multirow[t]{4}{*}{ P11511 } & \multirow{4}{*}{$\begin{array}{l}\text { Metabolic } \\
\text { pathways, Ovarian } \\
\text { steroidogenesis, } \\
\text { Steroid hormone } \\
\text { biosynthesis }\end{array}$} & $\begin{array}{l}\text { Naringenin 7-0-beta-D- } \\
\text { glucoside }\end{array}$ & EO \\
\hline & & & & Naringenin & EO \\
\hline & & & & Eriodictyol & EO \\
\hline & & & & $\begin{array}{l}\text { (2S)-Eriodictyol 7-0- } \\
\text { beta-D- } \\
\text { glucopyranoside }\end{array}$ & EO \\
\hline \multirow[t]{7}{*}{ EP300 } & \multirow{7}{*}{$\begin{array}{l}\text { Histone } \\
\text { acetyltransferase } \\
\text { p300 }\end{array}$} & \multirow[t]{7}{*}{ Q09472 } & \multirow{7}{*}{$\begin{array}{l}\text { FoxO signaling } \\
\text { pathway, HIF-1 } \\
\text { signaling pathway, } \\
\text { Jak-STAT signaling } \\
\text { pathway, Pathways } \\
\text { in cancer, Cell cycle, } \\
\text { cAMP signaling } \\
\text { pathway, Notch } \\
\text { signaling pathway }\end{array}$} & Calebin A & CL \\
\hline & & & & Curcumin & $\mathrm{CL}$ \\
\hline & & & & Letestuianin B & $\mathrm{CL}$ \\
\hline & & & & Demethoxycurcumin & $\mathrm{CL}$ \\
\hline & & & & $\begin{array}{l}\text { 1,7-bis(4-hydroxy-3- } \\
\text { methoxyphenyl)-1,4,6- } \\
\text { heptatrien-3-one }\end{array}$ & CL \\
\hline & & & & Dihydrocurcumin & $C L$ \\
\hline & & & & Go-Y022 & $\mathrm{CL}$ \\
\hline
\end{tabular}




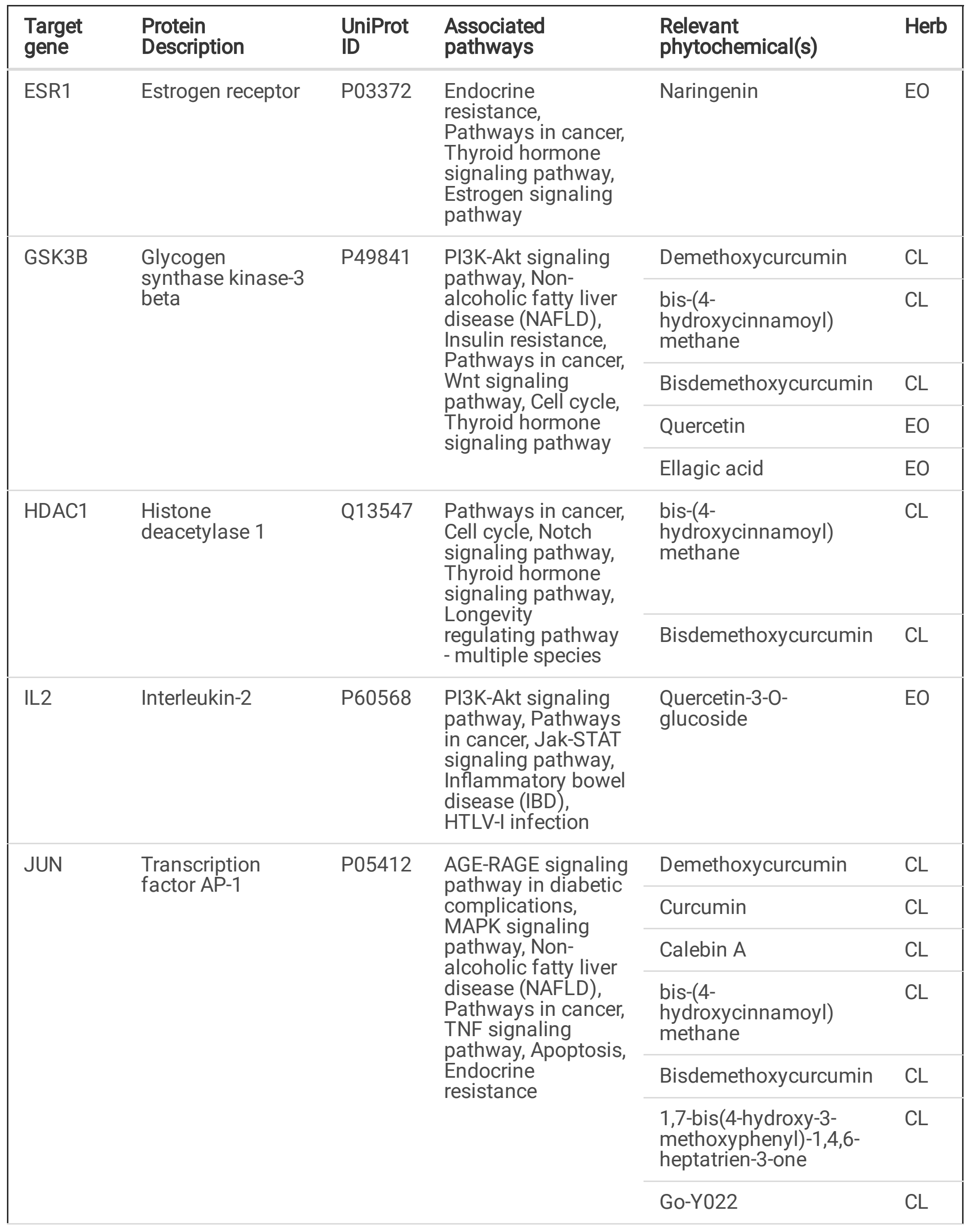




\begin{tabular}{|c|c|c|c|c|c|}
\hline $\begin{array}{l}\text { Target } \\
\text { gene }\end{array}$ & $\begin{array}{l}\text { Protein } \\
\text { Description }\end{array}$ & $\begin{array}{l}\text { UniProt } \\
\text { ID }\end{array}$ & $\begin{array}{l}\text { Associated } \\
\text { pathways }\end{array}$ & $\begin{array}{l}\text { Relevant } \\
\text { phytochemical(s) }\end{array}$ & Herb \\
\hline \multirow[t]{3}{*}{ MCL1 } & \multirow{3}{*}{$\begin{array}{l}\text { Induced myeloid } \\
\text { leukemia cell } \\
\text { differentiation } \\
\text { protein }\end{array}$} & \multirow[t]{3}{*}{ Q07820 } & \multirow{3}{*}{$\begin{array}{l}\text { Jak-STAT signaling } \\
\text { pathway, PI3K-Akt } \\
\text { signaling pathway, } \\
\text { Apoptosis, } \\
\text { MicroRNAs in } \\
\text { cancer }\end{array}$} & Corilagin & EO \\
\hline & & & & Indole-3-acetic acid & EO \\
\hline & & & & Chebulinic acid & EO \\
\hline \multirow[t]{4}{*}{ MMP2 } & \multirow[t]{4}{*}{$\begin{array}{l}72 \text { kDa type IV } \\
\text { collagenase }\end{array}$} & \multirow[t]{4}{*}{ P08253 } & \multirow{4}{*}{$\begin{array}{l}\text { AGE-RAGE signaling } \\
\text { pathway in diabetic } \\
\text { complications, } \\
\text { Endocrine } \\
\text { resistance, Estrogen } \\
\text { signaling pathway, } \\
\text { Pathways in cancer, } \\
\text { GnRH signaling } \\
\text { pathway }\end{array}$} & $\begin{array}{l}\text { bis-(4- } \\
\text { hydroxycinnamoyl) } \\
\text { methane }\end{array}$ & $\mathrm{CL}$ \\
\hline & & & & Bisdemethoxycurcumin & $\mathrm{CL}$ \\
\hline & & & & $\begin{array}{l}\text { Epigallocatechin } \\
\text { gallate }\end{array}$ & EO \\
\hline & & & & Quercetin & EO \\
\hline \multirow[t]{10}{*}{ MMP9 } & \multirow{10}{*}{$\begin{array}{l}\text { Matrix } \\
\text { metalloproteinase- } \\
9\end{array}$} & \multirow[t]{10}{*}{ P14780 } & \multirow{10}{*}{$\begin{array}{l}\text { Endocrine } \\
\text { resistance, Estrogen } \\
\text { signaling pathway, } \\
\text { IL-17 signaling } \\
\text { pathway, Pathways } \\
\text { in cancer, TNF } \\
\text { signaling pathway }\end{array}$} & Demethoxycurcumin & $\mathrm{CL}$ \\
\hline & & & & Calebin A & $\mathrm{CL}$ \\
\hline & & & & Curcumin & $\mathrm{CL}$ \\
\hline & & & & Letestuianin B & $\mathrm{CL}$ \\
\hline & & & & $\begin{array}{l}\text { bis-(4- } \\
\text { hydroxycinnamoyl) } \\
\text { methane }\end{array}$ & $\mathrm{CL}$ \\
\hline & & & & $\begin{array}{l}\text { 1,7-bis(4-hydroxy-3- } \\
\text { methoxyphenyl)-1,4,6- } \\
\text { heptatrien-3-one }\end{array}$ & $\mathrm{CL}$ \\
\hline & & & & Bisdemethoxycurcumin & CL \\
\hline & & & & Dihydrocurcumin & $\mathrm{CL}$ \\
\hline & & & & Go-Y022 & $\mathrm{CL}$ \\
\hline & & & & Quercetin & EO \\
\hline \multirow[t]{5}{*}{ NFKB1 } & \multirow{5}{*}{$\begin{array}{l}\text { Nuclear factor NF- } \\
\text { kappa-B p105 } \\
\text { subunit }\end{array}$} & \multirow[t]{5}{*}{ P19838 } & \multirow{5}{*}{$\begin{array}{l}\text { Insulin resistance, } \\
\text { AGE-RAGE signaling } \\
\text { pathway in diabetic } \\
\text { complications, } \\
\text { Apoptosis, PI3K-Akt } \\
\text { signaling pathway, } \\
\text { MAPK signaling } \\
\text { pathway, Longevity } \\
\text { regulating pathway, } \\
\text { NF-kappa B } \\
\text { signaling pathway, } \\
\text { Non-alcoholic fatty } \\
\text { liver disease }\end{array}$} & Demethoxycurcumin & $\mathrm{CL}$ \\
\hline & & & & Calebin A & $\mathrm{CL}$ \\
\hline & & & & Curcumin & $\mathrm{CL}$ \\
\hline & & & & Dihydrocurcumin & $\mathrm{CL}$ \\
\hline & & & & $\begin{array}{l}\text { 1,7-bis(4-hydroxy-3- } \\
\text { methoxyphenyl)-1,4,6- } \\
\text { heptatrien-3-one }\end{array}$ & $\mathrm{CL}$ \\
\hline
\end{tabular}

Page 10/30 


\begin{tabular}{|c|c|c|c|c|c|}
\hline \multirow[t]{2}{*}{$\begin{array}{l}\text { Target } \\
\text { gene }\end{array}$} & \multirow[t]{2}{*}{$\begin{array}{l}\text { Protein } \\
\text { Description }\end{array}$} & \multirow[t]{2}{*}{$\begin{array}{l}\text { UniProt } \\
\text { ID }\end{array}$} & $\begin{array}{l}\text { Associated } \\
\text { pathways }\end{array}$ & $\begin{array}{l}\text { Reilevant } \\
\text { phytochemical(s) }\end{array}$ & férb \\
\hline & & & $\begin{array}{l}\text { (NAFLD), Pathways } \\
\text { in cancer, TNF } \\
\text { signaling pathway }\end{array}$ & Letestuianin B & $\mathrm{CL}$ \\
\hline \multirow[t]{2}{*}{ NR3C1 } & \multirow{2}{*}{$\begin{array}{l}\text { Glucocorticoid } \\
\text { receptor }\end{array}$} & \multirow[t]{2}{*}{ P04150 } & \multirow{2}{*}{$\begin{array}{l}\text { HIF-1 signaling } \\
\text { pathway, FoxO } \\
\text { signaling pathway, } \\
\text { Thyroid hormone } \\
\text { signaling pathway, } \\
\text { Notch signaling } \\
\text { pathway, Estrogen } \\
\text { signaling pathway }\end{array}$} & Glycocholic acid & $\mathrm{CL}$ \\
\hline & & & & $\begin{array}{l}\text { Tauroursodeoxycholic } \\
\text { acid }\end{array}$ & $\mathrm{CL}$ \\
\hline NR4A1 & $\begin{array}{l}\text { Nuclear receptor } \\
\text { subfamily } 4 \text { group } \\
\text { A member } 1\end{array}$ & P22736 & $\begin{array}{l}\text { PI3K-Akt signaling } \\
\text { pathway, MAPK } \\
\text { signaling pathway }\end{array}$ & beta-carotene & EO \\
\hline PPARD & $\begin{array}{l}\text { Peroxisome } \\
\text { proliferator- } \\
\text { activated receptor } \\
\text { delta }\end{array}$ & Q03181 & $\begin{array}{l}\text { PPAR signaling } \\
\text { pathway, Wnt } \\
\text { signaling pathway, } \\
\text { Pathways in cancer }\end{array}$ & Arachidic acid & $\mathrm{CL}$ \\
\hline PPARG & $\begin{array}{l}\text { Peroxisome } \\
\text { proliferator- } \\
\text { activated receptor } \\
\text { gamma }\end{array}$ & P37231 & $\begin{array}{l}\text { PPAR signaling } \\
\text { pathway, AMPK } \\
\text { signaling pathway, } \\
\text { Longevity } \\
\text { regulating pathway }\end{array}$ & Arachidic acid & $\mathrm{CL}$ \\
\hline RXRA & $\begin{array}{l}\text { Retinoic acid } \\
\text { receptor RXR- } \\
\text { alpha }\end{array}$ & P19793 & $\begin{array}{l}\text { Non-alcoholic fatty } \\
\text { liver disease } \\
\text { (NAFLD), PI3K-Akt } \\
\text { signaling pathway, } \\
\text { PPAR signaling } \\
\text { pathway, Thyroid } \\
\text { hormone signaling } \\
\text { pathway, } \\
\text { Adipocytokine } \\
\text { signaling pathway, } \\
\text { Pathways in cancer }\end{array}$ & beta-carotene & EO \\
\hline
\end{tabular}

M-T-P network analysis. To visualize and construct an M-T-P network, the metabolites, potential targets, and associated pathways were imported into Cytoscape v3.8.2. The network contained 148 nodes and 578 edges with a network density of 0.053 (Supplementary file 6). Next, the M-T-P network using the T2DM related metabolites, potential targets, and associated pathways was constructed using Cytoscape v3.8.2 (Figure 7). The network showed 63 nodes and 197 edges with an average clustering coefficient of 0.088 and network density of 0.084 . In this network, phytochemicals like bisdemethoxycurcumin, bis-(4hydroxycinnamoyl) methane, and demethoxycurcumin showed the highest degree, each having ten targets suggesting that these compounds may be the significant phytochemicals of NA in treating T2DM. It was followed by curcumin, 1,7-bis(4-hydroxy-3-methoxyphenyl)-1,4,6-heptatrien-3-one, calebin A, and quercetin which had a degree equal to 8 . The network analysis showed that one metabolite could 
correspond to multiple targets, and one target could correspond to multiple metabolites and pathways. Thus, the network reflected the features of the synergetic relationships between the multiple metabolites, targets, and pathways of NA. Based on the M-T-P network, a proposed schematic diagram was drawn outlining the target proteins and pathways involved in T2DM (Figure 8).

\section{Discussion}

Traditional medicinal plants have been used for centuries to treat complex diseases such as cancer and diabetes ${ }^{30}$. Traditional medicinal systems generally use herbal formulations comprising multiple compatible herbs to improve therapeutic effect through synergism ${ }^{31}$. Moreover, it implements a comprehensive approach that focuses on supporting complete functional recovery and eradicating underlying cause of the disease. The concept of NP is comparable to the theory of the Traditional medicinal system. Hence, it is appropriate to explore the components and mechanism of action of complex Traditional herbal formulations using various databases and available software. The present work has explored the mechanism of action of NA, traditionally used in India to treat T2DM. The network module approach and widely used enrichment analysis methods have been utilized to uncover the concealed information within the target PPI network. In this study, 201 phytochemicals in NA were predicted by network analysis, of which 20 have been found to have anti-diabetic effects. Subsequently, we found that these metabolites have therapeutic effects through regulating various T2DM related target proteins of different metabolic pathways.

T2DM is a chronic, multifactorial metabolic disorder involving insulin insensitivity due to insulin resistance, reduced insulin production, and, eventually, pancreatic $\beta$-cell dysfunction ${ }^{32,33}$. There is reduced transportation of glucose into the liver, muscle, and fat cells and a rise in fat breakdown and hyperglycemia. NP analysis showed that the phytochemicals of NA such as quercetin, ellagic acid, quercetin-3-0-glucoside, demethoxycurcumin, bisdemethoxycurcumin, beta-carotene, arachidic acid, and bis-(4-hydroxycinnamoyl) methane could induce insulin secretion, ameliorate insulin resistance, and elevate utilization of glucose by acting on AKT1, GSK3B, PPAR-y, NR4A1, and IL-2. Pathway analysis revealed that these proteins modulate PI3K-Akt, PPAR, Jak-STAT, AMPK, and MAPK signaling pathways and regulate inflammation, gluconeogenesis, lipid metabolism, and cell cycle. We also found phytochemicals such as curcumin, bisdemethoxycurcumin, demethoxycurcumin, calebin A, Go-Y022, epigallocatechin gallate, and 1,7-bis(4-hydroxy-3-methoxyphenyl)-1,4,6-heptatrien-3-one can regulate proteins like NF-KB, JUN, Mcl-1, and Bcl-2 through NF-kappa B, TNF, and HIF-1 signaling pathways.

The results are consistent with the earlier studies suggesting that these proteins and pathways play a crucial role in the pathophysiology of T2DM. PI3K/Akt signaling pathway activation induces insulin secretion from pancreatic $\beta$-cells ${ }^{34,35}$. Also, activation of AKT and its downstream signaling intermediates, viz., GSK3, mTOR1, and Fox01, leads to increased proliferation, mass, and cell size of pancreatic $\beta$-cells ${ }^{36}$. It regulates various signaling pathways such as NF-KB, MAPK, and FoxO. These pathways play a crucial role in regulating protein synthesis, cell differentiation, proliferation, cell survival, 
and apoptosis ${ }^{37}$. NR4A1 protein is elevated in response to glucose and saturated fatty acids in pancreatic $\beta$-cells ${ }^{38,39}$, further regulating cell proliferation and insulin secretion ${ }^{40}$. Knockout of NR4A1 has been shown to reduce $\beta$-cell density in the islets ${ }^{41}$. Another protein, p300 (EP300), is a transcriptional coactivator, and many $\beta$-cell transcription factors require p300 along with CBP protein. Studies have shown that p300 is a limiting cofactor for islet development, making it vital for $\beta$-cell function and health in vivo ${ }^{42}$.

In insulin resistance, glucose tolerance is decreased in response to $\beta$-cell dysfunction ${ }^{43}$. The $\beta$-cells dysfunction is caused by numerous factors, such as oxidative stress and inflammation, and the FoxO pathway is highly linked to these risk factors ${ }^{44}$. Also, the AMPK protein activity is reduced in skeletal muscles and liver reduces in insulin resistance, leading to reduced free fatty acid oxidation and a lesser glucose intake, which deteriorates glycemic control ${ }^{45}$. Peroxisome proliferator-activated receptor (PPAR- $\gamma$ ) is a nuclear hormone receptor expressed primarily in the adipose tissues ${ }^{46}$. Apart from increasing insulin sensitivity in peripheral tissues, PPAR-y has also been shown to enhance the glucose-sensing ability of pancreatic $\beta$-cells. It has been also shown to improve glucose homeostasis by directly affecting the liver and pancreatic $\beta$-cells ${ }^{47}$. Furthermore, GSK3B is postulated to be a potential kinase that induces insulin resistance. It can directly phosphorylate the IR and IRS-1 at Ser residues, thereby attenuating the insulinstimulated phosphorylation of their Tyr residues ${ }^{48}$.

NA phytochemicals could also regulate the TNF signaling pathway, which induces many cascade reactions, such as stimulating the transcription factor NF-KB, inflammatory response ${ }^{49,50}$, and apoptosis ${ }^{51}$. Research has shown that the TNF signaling pathway, a negative feedback mechanism, inhibits cell death by activating NF-KB ${ }^{52}$. TNF- $a$ induces inflammation in pancreatic islets, leading to apoptosis in pancreatic $\beta$-cells ${ }^{53-55}$. In addition, TNF-a down-regulates PI3K/Akt signaling pathway and activates transcriptional factor NF-KB, an essential modulator of pancreatic cell death ${ }^{56-58}$. The activated signal transduction eventually initiates pancreatic $\beta$-cell apoptosis by regulating several proteins such as $\mathrm{Bcl}-2$ and $\mathrm{Mcl}-1^{59-61}$. The $\mathrm{Bcl}-2$ regulates the mitochondrial-mediated $\beta$-cell apoptosis triggered by proinflammatory cytokines. Few Bcl-2 family proteins also play important role in regulation of $\beta$-cell function and glucose metabolism ${ }^{62}$. T2DM is associated with impaired wound healing, resulting from complex pathophysiology involving vascular, immune, neuropathic, and biochemical components ${ }^{13}$. The network analysis showed that NA regulates MMP-9, which exhibited a protective role in diabetic mice by improving wound healing ${ }^{63,64}$. It suggests that NA could play a vital role in improving healing diabetic ulcers.

Our network analysis is supported by pre-clinical studies using phytochemicals of NA. Curcumin has been reported to inhibit TNF- $a^{65,66}$, caspase- $3^{67}$, and JNK phosphorylation ${ }^{68,69}$ and induces Bcl-2 activity ${ }^{67}$. In addition, it has also been shown to upregulate PPAR-y via AMPK activation ${ }^{70}$. Quercetin upregulates AKT expression and follows the AMPK-P38 MAPK pathway to induce glucose uptake, which may contribute to correcting insulin resistance via bypassing the GLUT4 translocation via insulin-regulated system ${ }^{71}$. 
Ellagic acid exerts anti-diabetic activity by inducing insulin secretion and reducing glucose intolerance in pancreatic $\beta$-cells. Also, increased $\beta$-cell size and number in diabetic rats ${ }^{72}$. Also, epigallocatechin gallate has been reported to reduce oxidative stress, pro-inflammatory cytokines (TNF- $\alpha$ and IL-6), p53, and caspase levels, and upregulate $\mathrm{Bcl}-2$ in diabetic rats suggesting its anti-inflammatory and anti-apoptotic action $^{73}$.

Network analysis has revealed that NA may also be explored in other diseases. In our study, phytochemicals of NA were putatively associated with pathways involved in leukemia, anemia, infertility, renal failure, hepatitis, fatigue, dermatitis, hyperhidrosis, etc. Interestingly, the description of CL and EO in Ayurvedic classical texts also supports their use in tvak dosa (skin disorders), rasayana (rejuvenator), shotha (inflammatory disorders), sveda (excessive sweating), pandu (hematological disorders), etc. ${ }^{74,75}$. The experimental studies further support these facts. CL and EO have been reported to treat tumor ${ }^{76,77}$, Alzheimer $^{78,79}$, obesity ${ }^{80,81}$ anxiety disorders ${ }^{82,83}$, infertility ${ }^{84,85}$, and anemia ${ }^{86,87}$. Indications of different NA phytochemicals correspond to synergistic effects of polyherbal formulas used in traditional medicine. Accordingly, NP seems to be an appropriate approach to study the complex traditional herbal formulations.

\section{Conclusion}

T2DM is a disease with complex pathogenesis, comprised of multiple targets and cross-linked signaling pathways. NP based approach showed that curcumin and its derivatives, bis-(4-hydroxycinnamoyl) methane, 1,7-bis(4-hydroxy-3-methoxyphenyl)-1,4,6-heptatrien-3-one, calebin A, and quercetin regulated various targets associated with T2DM viz., AKT1, GSK3B, (PPAR)-y, NR4A1, NF-kappa B, JUN, Mcl-1, Bcl-2, and IL-2. In addition, NA may regulate T2DM by modulating glucose and lipid metabolism, $\beta$-cell survival and proliferation, regulation of insulin resistance, inflammation, apoptosis, and cell cycle through PI3KAkt, TNF, FoxO, Jak-STAT, MAPK, and NF-kappa B signaling pathway. Therefore, the results suggest that its anti-diabetic effect's underlying mechanism is a direct or indirect synergism of multiple targets and pathways. Though, additional experimental studies are necessary to reveal the anti-diabetic effect of NA.

\section{Materials And Methods}

Phytochemical compounds of Nisha Amalaki. The phytochemicals/metabolites of CL and EO were collected from compound databases including PubChem (https://pubchem.ncbi.nlm.nih.gov/) ${ }^{88}$, KNApSAcK (http://knapsackfamily.com/knapsack_core/top.php) ${ }^{89}$, Indian Medicinal Plants, Phytochemistry and Therapeutics (IMPPAT, https://cb.imsc.res.in/imppat/) ${ }^{90}$, and Chemical Entities of Biological Interest (ChEBI, https://www.ebi.ac.uk/chebi/) ${ }^{91}$.

Identification of NA target genes. The target genes of phytochemical compounds from NA herbal formulation were identified using the similarity ensemble approach (SEA; http://sea.bkslab.org/) ${ }^{92}$. It is a chemical similarity search-based prediction tool known worldwide for its accuracy ${ }^{93,94}$. Although the SEA 
approach account only for $\sim 2,800$ potentially active proteins as alternate binding targets, the method is coherent with the already identified druggable genome $(\sim 3000)^{95-97}$.

Target PPI network construction and module identification. The target genes selected above were used to build a PPI network using NetworkAnalyst 3.0 tool (http://www.networkanalyst.ca/) ${ }^{98,99}$. The network construction was constrained to contain only the original seed proteins by choosing the zero-order interactions in order to avoid the "hairball effect." NetworkAnalyst 3.0 incorporates extensive PPI data from already published literature with experimental evidence accessible across various PPI related databases such as IntAct ${ }^{100}$, BIND $^{101}$, MINT $^{102}$, BioGRID ${ }^{103}$, and DIP ${ }^{104}$, integrated into InnateDB ${ }^{105}$. The tightly associated group of target proteins, also referred to as modules in the PPI network, was identified using the "module explorer" tool of NetworkAnalyst 3.0 that uses a random walk-based method for detecting modules. Wilcoxon rank-sum test was used to calculate the $P$-value of the modules ${ }^{106}$, and the modules with significant $P$-value $(P \leq .001)$ were selected. The selected module was analyzed using the NetworkAnalyzer tool v4.4.8 within Cytoscape v3.8.2 $2^{107}$.

GO and KEGG pathway enrichment analysis. GO enrichment analysis, and KEGG pathway annotation were carried out to elucidate the role of target genes that interact with the phytochemicals of NA using the Database for Annotation, Visualization and Integrated Discovery (DAVID, https://david.ncifcrf.gov/) v6.8 ${ }^{108}$ and NetworkAnalyst 3.0 tool, respectively. The GO analysis provides a curated and predicted annotation of genes with standardized terms relating to cellular components, biological processes, and molecular functions. The GO term was restricted to $P \leq .01$, which is based on the false discovery rate (FDR; Benjamini-Hochberg). The enriched KEGG pathways with adjusted $P$-value, i.e., FDR $\leq .01$ were used for the subsequent analysis.

Gene-Disease network construction. To identify the diseases associated with the target genes in the significant module gene-disease network was constructed using the 'gene-disease associations' network mapping tool available on NetworkAnalyst 3.0 platform. This tool uses the literature curated gene-disease association data gathered using DisGeNET database (https://www.disgenet.org/). The DisGeNET database contains most comprehensive collections of genes and variants associated with human diseases $^{109}$.

Identification of target genes related to T2DM. Genes related to T2DM were identified after the screening of different databases, including Online Mendelian Inheritance in Man (OMIM; http://www.omim.org/), DrugBank database (http://www.drugbank.ca/), Therapeutic Target Database (TTD; http://db.idrblab.net/ttd/), and KEGG Disease (https://www.genome.jp/kegg/disease/). The gene names were validated using UniProt database (https://www.uniprot.org/). The gene list was further used to identify the T2DM related genes in the significant module.

Construction of the M-T-P network. The NA metabolites, target genes, and the related KEGG pathway were all imported into Cytoscape v3.8.2 to establish a M-T-P network. The nodes denote metabolites, targets, and pathways in the network, while the edges denote the interaction between the nodes. 


\section{Declarations}

\section{Acknowledgements}

Authors acknowledge Ministry of AYUSH, Government of India, for support through Centre of Excellence scheme to Centre for Integrative Medicine and Research (CIMR), AlIMS, New Delhi. The authors also acknowledge Ms. Ritu Chauhan, CSIR-Institute of Genomics and Integrative Biology, New Delhi, India for preparing KEGG pathway scatter plot using R software.

\section{Author Contributions}

M.W., V.C., B.K.K., V.S., and S.R. conceived and designed the study; M.W., V.C., P.K., and A.K. analyzed and interpreted the data; M.W. wrote the manuscript; V.C., A.K., B.K.K., and V.S. reviewed the manuscript and carried out extensive revisions to the manuscript. G.S. conceptualized, visualized, supervised, and reviewed the manuscript. All authors read and approved the final content.

\section{Competing Interests}

The authors declare no competing interests.

\section{References}

1. Zimmet, P., Cowie, C., Ekoe, J. M. \& Shaw, J. Classification of Diabetes Mellitus and Other Categories of Glucose Intolerance. in International Textbook of Diabetes Mellitus (ed. Ralph A. DeFronzo MD, Ele Ferrannini MD, Paul Zimmet AO, MD, PhD, FRACP, FRCP, FTSE, K. G. M. M. A.)(2003). doi:10.1002/0470862092.d0101.

2. Diabetes. https://www.who.int/health-topics/diabetes\#tab=tab_1.

3. American Diabetes Association. Pharmacologic approaches to glycemic treatment: Standards of medical care in diabetes-2019., 42, S90-S102 (2019).

4. Chaudhury, A. et al. Clinical Review of Antidiabetic Drugs: Implications for Type 2 Diabetes Mellitus Management. Front. Endocrinol. (Lausanne). 8, (2017).

5. Tong, X. L., Dong, L., Chen, L. \& Zhen, Z. Treatment of diabetes using traditional Chinese medicine: Past, present and future. Am. J. Chin. Med, 40, 877-886 (2012).

6. Akash, M. S. H., Rehman, K., Tariq, M. \& Chen, S. Zingiber officinale and type 2 diabetes mellitus: Evidence from experimental studies. Crit. Rev. Eukaryot. Gene Expr, 25, 91-112 (2015).

7. Akash, M. S. H., Rehman, K. \& Chen, S. Spice plant Allium cepa: Dietary supplement for treatment of type 2 diabetes mellitus. Nutrition, 30, 1128-1137 (2014).

8. Dhawan, B. N. \& Rastogi, A. K. Perspectives of Indian Medicinal Plants in the Management of Diabetes Mellitus (Indian Council of Medical Research, 2014).

9. Modak, M., Dixit, P., Londhe, J., Ghaskadbi, S. \& Devasagayam, T. P. A. Indian herbs and herbal drugs used for the treatment of diabetes. J. Clin. Biochem. Nutr, 40, 163-173 (2007). 
10. Damle, N. Clinical Study To Evaluate Efficacy of Nisha Amalaki Churna in Newly Diagnosed Prameha Type li Diabetes Mellitus. Indian J. Appl. Res, 11, 42-43 (2021).

11. Bansal, D. C., Jain, D. R., Shukla, D. U. \& Paul, D. S. Preventive scope of Nishamalaki Churna (combination of turmeric and Indian gooseberry powder) in type 2 DM: Review. Int. J. Pharmacogn. Life Sci, 1, $01-05$ (2020).

12. Gogte, V. M. Part II: Medicinal plants. Ayurvedic Pharmacology and Therapeutics Uses of Medicinal Plants (Dravyagunavigyan) (Chaukhambha Publications, 2000).

13. Greenhalgh, D. G. Wound healing and diabetes mellitus. Clin. Plast. Surg, 30, 37-45 (2003).

14. Nishiyama, T. et al. Curcuminoids and sesquiterpenoids in turmeric (Curcuma longa L.) Suppress an increase in blood glucose level in type 2 diabetic KK-Ay mice. J. Agric. Food Chem, 53, 959-963 (2005).

15. Na, L. X. et al. Curcuminoids exert glucose-lowering effect in type 2 diabetes by decreasing serum free fatty acids: A double-blind, placebo-controlled trial. Mol. Nutr. Food Res, 57, 1569-1577 (2013).

16. Na, L. X. et al. Curcuminoids target decreasing serum adipocyte-fatty acid binding protein levels in their glucose-lowering effect in patients with type 2 diabetes. Biomed. Environ. Sci, 27, 902-906 (2014).

17. Ghorbani, Z., Hekmatdoost, A. \& Mirmiran, P. Anti-hyperglycemic and insulin sensitizer effects of turmeric and its principle constituent curcumin. Int. J. Endocrinol. Metab, 12, 1-9 (2014).

18. Krishnaveni, M. \& Mirunalini, S. Therapeutic potential of phyllanthus emblica (amla): The ayurvedic wonder. J. Basic Clin. Physiol. Pharmacol, 21, 93-105 (2010).

19. Variya, B. C., Bakrania, A. K. \& Patel, S. S. Emblica officinalis (Amla): A review for its phytochemistry, ethnomedicinal uses and medicinal potentials with respect to molecular mechanisms. Pharmacol. Res, 111, 180-200 (2016).

20. Patel, S. S. \& Goyal, R. K. Emblica officinalis geart.: A comprehensive review on phytochemistry, pharmacology and ethnomedicinal uses. Research Journal of Medicinal Plant, 6, 6-16 (2012).

21. Zuo, H. et al. A network pharmacology-based approach to analyse potential targets of traditional herbal formulas: An example of Yu Ping Feng decoction. Sci. Rep, 8, 1-15 (2018).

22. Tao, W. et al. Network pharmacology-based prediction of the active ingredients and potential targets of Chinese herbal Radix Curcumae formula for application to cardiovascular disease. J. Ethnopharmacol, 145, 1-10 (2013).

23. Zhang, Q. et al. Natural formulas and the nature of formulas: Exploring potential therapeutic targets based on traditional Chinese herbal formulas. PLoS One, 12, 1-14 (2017).

24. Mao, Y. et al. Network pharmacology-based and clinically relevant prediction of the active ingredients and potential targets of Chinese herbs in metastatic breast cancer patients. Oncotarget, 8, 2700727021 (2017).

25. Kibble, M. et al. Network pharmacology applications to map the unexplored target space and therapeutic potential of natural products. Nat. Prod. Rep, 32, 1249-1266 (2015). 
26. Bi, Y. H., Zhang, L. H., Chen, S. J. \& Ling, Q. Z. Antitumor Mechanisms of Curcumae Rhizoma Based on Network Pharmacology. Evidence-based Complement. Altern. Med. 2018, (2018).

27. Raman, K. Construction and analysis of protein-protein interaction networks. Autom. Exp, 2, 1-11 (2010).

28. Yu, H., Kim, P. M., Sprecher, E., Trifonov, V. \& Gerstein, M. The importance of bottlenecks in protein networks: Correlation with gene essentiality and expression dynamics. PLoS Comput. Biol, 3, 713720 (2007).

29. Jeong, H., Mason, S. P., Barabási, A. L. \& Oltvai, Z. N. Lethality and centrality in protein networks. Nature, 411, 41-42 (2001).

30. Choudhari, A. S., Mandave, P. C., Deshpande, M., Ranjekar, P. \& Prakash, O. Phytochemicals in cancer treatment: From preclinical studies to clinical practice. Front. Pharmacol, 10, 1-17 (2020).

31. Li, Y. et al. A Novel Method for Evaluating the Cardiotoxicity of Traditional Chinese Medicine Compatibility by Using Support Vector Machine Model Combined with Metabonomics. Evidencebased Complement. Altern. Med. 2016, (2016).

32. Kahn, C. R. Banting Lecture. Insulin action, diabetogenes, and the cause of type II diabetes., 43 , 1066-1084 (1994).

33. Olokoba, A. B., Obateru, O. A. \& Olokoba, L. B. Type 2 diabetes mellitus: A review of current trends. Oman Med. J, 27, 269-273 (2012).

34. Dor, Y., Brown, J., Martinez, O. I. \& Melton, D. A. Adult pancreatic beta-cells are formed by selfduplication rather than stem-cell differentiation. Nature, 429, 41-46 (2004).

35. Georgia, S. \& Bhushan, A. B Cell Replication Is the Primary Mechanism for Maintaining Postnatal B Cell Mass. J. Clin. Invest, 114, 963-968 (2004).

36. Bernal-Mizrachi, E., Wen, W., Stahlhut, S., Welling, C. M. \& Permutt, M. A. Islet $\beta$ cell expression of constitutively active Akt1/PKBa induces striking hypertrophy, hyperplasia, and hyperinsulinemia. J. Clin. Invest, 108, 1631-1638 (2001).

37. Hers, I., Vincent, E. E. \& Tavaré, J. M. Akt signalling in health and disease. Cell. Signal, 23, 1515-1527 (2011).

38. Susini, S., Roche, E., Prentki, M. \& Schlegel, W. Glucose and glucoincretin peptides synergize to induce c- fos, c- jun, junB, zif -268, and nur- 77 gene expression in pancreatic $\beta($ INS-1) cells. FASEB J, 12, 1173-1182 (1998).

39. Roche, E. et al. Palmitate and oleate induce the immediate-early response genes c-fos and nur-77 in the pancreatic beta-cell line INS-1., 48, 2007-2014 (1999).

40. Briand, 0 . et al. The nuclear orphan receptor Nur77 is a lipotoxicity sensor regulating glucose-induced insulin secretion in pancreatic $\beta$-cells. Mol. Endocrinol, 26, 399-413 (2012).

41. Tessem, J. S. et al. Nkx6.1 regulates islet $\beta$-cell proliferation via Nr4a1 and Nr4a3 nuclear receptors. Proc. Natl. Acad. Sci. U. S. A. 111, 5242-5247(2014). 
42. Wong, C. K. et al. The p300 and CBP transcriptional coactivators are required for $\beta$-cell and a-cell proliferation., 67, 412-422 (2018).

43. Oliveira, J. M., Rebuffat, S. A., Gasa, R. \& Gomis, R. Targeting type 2 diabetes: lessons from a knockout model of insulin receptor substrate 2. Can. J. Physiol. Pharmacol, 92, 613-620 (2014).

44. Kitamura, T. The role of FOXO1 in $\beta$-cell failure and type 2 diabetes mellitus. Nat. Rev. Endocrinol, 9 , 615-623 (2013).

45. Russo, G. L., Russo, M. \& Ungaro, P. AMP-activated protein kinase: A target for old drugs against diabetes and cancer. Biochem. Pharmacol, 86, 339-350 (2013).

46. Didier Auboeuf, J. et al. and H. V. \& Members. Tissue Distribution and Quantification of the Expression of mRNAs of Peroxisome Proliferator-Activated Receptors and Liver X Receptor-a in Humans., 46, 1319-1327 (1997).

47. Kim, H. \& Ahn, Y. Role of peroxisome proliferator-activated receptor-gamma in the glucose-sensing apparatus of liver and beta-cells., 53 (Suppl 1), S60-5 (2004).

48. Lee, J. \& Kim, M. S. The role of GSK3 in glucose homeostasis and the development of insulin resistance.Diabetes Res. Clin. Pract.77, (2007).

49. Mavrogonatou, E., Konstantinou, A. \& Kletsas, D. Long-term exposure to TNF-a leads human skin fibroblasts to a p38 MAPK- and ROS-mediated premature senescence., 19, 237-249 (2018).

50. Ji, M. et al. C5a induces the synthesis of IL-6 and TNF-a in rat glomerular mesangial cells through MAPK signaling pathways. PLoS One, 11, 1-17 (2016).

51. Van Antwerp, D. J., Martin, S. J., Kafri, T., Green, D. R. \& Verma, I. M. Suppression of TNF-a-induced apoptosis by NF-KB. Science (80-.), 274, 787-789 (1996).

52. Ge, Q. et al. Analysis of mulberry leaf components in the treatment of diabetes using network pharmacology. Eur. J. Pharmacol, 833, 50-62 (2018).

53. Rehman, K. \& Akash, M. S. H. Mechanisms of inflammatory responses and development of insulin resistance: How are they interlinked? J. Biomed. Sci, 23, 1-18 (2016).

54. Akash, M. S. H., Shen, Q., Rehman, K. \& Chen, S. Interleukin-1 receptor antagonist: a new therapy for type 2 diabetes mellitus. J. Pharm. Sci, 101, 1647-1658 (2012).

55. Akash, M. S. H., Rehman, K. \& Chen, S. Role of inflammatory mechanisms in pathogenesis of type 2 diabetes mellitus. J. Cell. Biochem, 114, 525-531 (2013).

56. Parkash, J., Chaudhry, M. A. \& Rhoten, W. B. Tumor necrosis factor-a-induced changes in insulinproducing $\beta$-cells. Anat. Rec. - Part A Discov. Mol. Cell. Evol. Biol, 286, 982-993 (2005).

57. Donath, M. Y. \& Shoelson, S. E. Type 2 diabetes as an inflammatory disease. Nat. Rev. Immunol, 11, 98-107 (2011).

58. Zhang, J. \& Liu, F. Tissue-specific insulin signaling in the regulation of metabolism and aging. IUBMB Life, 66, 485-495 (2014).

59. Thomas, H. E., McKenzie, M. D., Angstetra, E., Campbell, P. D. \& Kay, T. W. Beta cell apoptosis in diabetes., 14, 1389-1404 (2009). 
60. Eizirik, D. L., Cardozo, A. K. \& Cnop, M. The role for endoplasmic reticulum stress in diabetes mellitus. Endocr. Rev, 29, 42-61 (2008).

61. Allagnat, $\mathrm{F}$. et al. $\mathrm{Mcl}-1$ downregulation by pro-inflammatory cytokines and palmitate is an early event contributing to B-cell apoptosis. Cell Death Differ, 18, 328-337 (2011).

62. Gurzov, E. N. \& Eizirik, D. L. Bcl-2 proteins in diabetes: Mitochondrial pathways of $\beta$-cell death and dysfunction. Trends Cell Biol, 21, 424-431 (2011).

63. Kang, L., Mayes, W. H., James, F. D., Bracy, D. P. \& Wasserman, D. H. Matrix metalloproteinase 9 opposes diet-induced muscle insulin resistance in mice., 57, 603-613 (2014).

64. Cho, H. et al. Diabetic wound healing in a MMP9-/-mouse model. Wound Repair Regen, 24, 829-840 (2016).

65. Jain, S. K., Rains, J., Croad, J., Larson, B. \& Jones, K. Curcumin supplementation lowers TNF-a, IL-6, IL-8, and MCP-1 secretion in high glucose-treated cultured monocytes and blood levels of TNF-a, IL-6, MCP-1, glucose, and glycosylated hemoglobin in diabetic rats. Antioxidants Redox Signal, 11, 241249 (2009).

66. Gonzales, A. M. \& Orlando, R. A. Curcumin and resveratrol inhibit nuclear factor-kappaB-mediated cytokine expression in adipocytes. Nutr. Metab, 5, 1-13 (2008).

67. Yu, W. et al. Curcumin Alleviates Diabetic Cardiomyopathy in Experimental Diabetic Rats. PLoS One, 7, 1-11 (2012).

68. Pan, Y. et al. Inhibition of JNK phosphorylation by a novel curcumin analog prevents high glucoseinduced inflammation and apoptosis in cardiomyocytes and the development of diabetic cardiomyopathy., 63, 3497-3511 (2014).

69. Ren, J. \& Sowers, J. R. Application of a novel curcumin analog in the management of diabetic cardiomyopathy., 63, 3166-3168 (2014).

70. Jiménez-Flores, L. M. et al. NF-KB and AMPK-Dependent mechanism may be involved in the beneficial effects of curcumin in the diabetic db/db mice liver., 19, 8289-8302 (2014).

71. Dhanya, R., Arya, A. D., Nisha, P. \& Jayamurthy, P. Quercetin, a lead compound against type 2 diabetes ameliorates glucose uptake via AMPK pathway in skeletal muscle cell line. Front. Pharmacol, 8, 1-9 (2017).

72. Fatima, N. et al. Ellagic acid in Emblica officinalis exerts anti-diabetic activity through the action on $\beta$ cells of pancreas. Eur. J. Nutr, 56, 591-601 (2017).

73. Othman, A. I., El-Sawi, M. R., El-Missiry, M. A. \& Abukhalil, M. H. Epigallocatechin-3-gallate protects against diabetic cardiomyopathy through modulating the cardiometabolic risk factors, oxidative stress, inflammation, cell death and fibrosis in streptozotocin-nicotinamide-induced diabetic rats. Biomed. Pharmacother, 94, 362-373 (2017).

74. Gupta, K. A. Chikitsa sthan. in Astanghrdayam by Vagbhata, Vidyotini Hindi Commentary (ed. Upadhyay, V. Y.) 672(Chaukhambha Sanskrit Sansthan, 2005). 
75. Gupta, K. A. Uttar Tantra. in Astanghrdayam by Vagbhata, Vidyotini Hindi Commentary (ed. Upadhyaya, V. Y.) 611(Chaukhambha Sanskrit Sansthan, 2005).

76. Pan, Y. et al. Berberine enhances chemosensitivity and induces apoptosis through dose-orchestrated AMPK signaling in breast cancer. J. Cancer, 8, 1679-1689 (2017).

77. Weng, J. R. et al. Cucurbitane triterpenoid from momordica charantia induces apoptosis and autophagy in breast cancer cells, in part, through peroxisome proliferator-activated receptor $Y$ activation. Evidence-based Complement. Altern. Med. 2013, (2013).

78. Chen, M. et al. Use of curcumin in diagnosis, prevention, and treatment of Alzheimer's disease. Neural Regen. Res, 13, 742-752 (2018).

79. Justin Thenmozhi, A., Dhivyabharathi, M., Raja, W., Manivasagam, T. R., Essa, M. M. \& T. \& Tannoid principles of Emblica officinalis renovate cognitive deficits and attenuate amyloid pathologies against aluminum chloride induced rat model of Alzheimer's disease. Nutr. Neurosci, 19, 269-278 (2016).

80. Yadav, K. D. \& Chaudhury, A. K. Anti-obesity mechanism of curcuma longa L. - An over view. Indian J. Nat. Prod. Resour, 7, 99-106 (2016).

81. Nazish, I. \& Ansari, S. H. Emblica officinalis - Anti-obesity activity. J. Complement. Integr. Med, 15, 111 (2018).

82. Lee, B. \& Lee, H. Systemic Administration of Curcumin Affect Anxiety-Related Behaviors in a Rat Model of Posttraumatic Stress Disorder via Activation of Serotonergic Systems. Evidence-based Complement. Altern. Med. 2018, (2018).

83. Pemminati, S. et al. Antianxiety effect of aqueous extract of fruits of Emblica officinalis(EO) on acute and chronic administration in rats. J. Pharm. Res, 3, 219-233 (2010).

84. Olanrewaju, A. J. et al. In vivo evidences of Curcuma longa on oxidative stress in STZ-induced diabetes on sperm parameters in male wistar rats. Anat. J. Africa, 6, 1045-1051 (2017).

85. Sinha, P. \& Kumari, A. Amelioration Effect of Emblica officinalis Extract on Ovary in Endosulfan Induced Swiss Albino Mice. Br. J. Pharm. Res, 11, 1-9 (2016).

86. Nadirah, S., Mulyantoro, D. K. \& Wahyuni, S. Potential of Turmeric (Curcuma Longa) in Increasing Hemoglobin Levels: Systematic Literature Review. Str. J. IIm. Kesehat, 9, 1422-1433 (2020).

87. Akter, T. et al. Haematopoietic Effects of Amloki (Emblica officinalis) in Pregnancy with Iron Deficiency Anaemia. J. Biosci. Med, 08, 157-165 (2020).

88. Kim, S. et al. PubChem substance and compound databases. Nucleic Acids Res, 44, D1202-D1213 (2016).

89. Afendi, F. M. et al. KNApSAcK family databases: Integrated metabolite-plant species databases for multifaceted plant research. Plant Cell Physiol, 53, 1-12 (2012).

90. Mohanraj, K. et al. A curated database of Indian Medicinal Plants, Phytochemistry and Therapeutics. Sci. Rep. 8, IMPPAT, 1-17 (2018). 
91. Hastings, J. et al. ChEBI in 2016: Improved services and an expanding collection of metabolites. Nucleic Acids Res. 44, D1214-D1219 (2016).

92. Keiser, M. J. et al. Relating protein pharmacology by ligand chemistry. Nat. Biotechnol, 25, 197-206 (2007).

93. Keiser, M. J. et al. Predicting new molecular targets for known drugs. Nature, 462, 175-181 (2009).

94. Lounkine, E. et al. Large-scale prediction and testing of drug activity on side-effect targets. Nature, 486, 361-367 (2012).

95. Hopkins, A. L. \& Groom, C. R. The druggable genome. Nat. Rev. Drug Discov, 1, 727-730 (2002).

96. Rodgers, G. et al. Glimmers in illuminating the druggable genome. Nat. Rev. Drug Discov, 17, 301302 (2018).

97. Russ, A. P. \& Lampel, S. The druggable genome: An update. Drug Discov. Today, 10, 1607-1610 (2005).

98. Xia, J., Benner, M. J. \& Hancock, R. E. W. NetworkAnalyst - Integrative approaches for protein-protein interaction network analysis and visual exploration. Nucleic Acids Res, 42, 167-174 (2014).

99. Zhou, G. et al. NetworkAnalyst 3.0: A visual analytics platform for comprehensive gene expression profiling and meta-analysis. Nucleic Acids Res, 47, W234-W241 (2019).

100. Orchard, S. et al. The MIntAct project - IntAct as a common curation platform for 11 molecular interaction databases. Nucleic Acids Res, 42, 358-363 (2014).

101. Isserlin, R., El-Badrawi, R. A. \& Badery, G. D. The biomolecular interaction network database in PSI-MI 2.5. Database 2011, 1-16 (2011).

102. Licata, L. et al. MINT, the molecular interaction database: 2012 Update. Nucleic Acids Res, 40, 857861 (2012).

103. Chatr-Aryamontri, A. et al. The BioGRID interaction database: 2015 update. Nucleic Acids Res, 43, D470-D478 (2015).

104. Salwinski, L. et al. The Database of Interacting Proteins: 2004 update. Nucleic Acids Res, 32, 449451 (2004).

105. Breuer, K. et al. InnateDB: Systems biology of innate immunity and beyond - Recent updates and continuing curation. Nucleic Acids Res, 41, 1228-1233 (2013).

106. Haynes, W. Wilcoxon Rank Sum Test. in Encyclopedia of Systems Biology 2354-2355(Springer New York, 2013). doi:10.1007/978-1-4419-9863-7_1185.

107. Paul Shannon, 1 et al. Cytoscape: A Software Environment for Integrated Models. Genome Res. 13, 426 (1971).

108. Jiao, X. et al. DAVID-WS: A stateful web service to facilitate gene/protein list analysis., 28, 18051806 (2012).

109. Piñero, J. et al. The DisGeNET knowledge platform for disease genomics: 2019 update. Nucleic Acids Res, 48, D845-D855 (2020). 
Figures

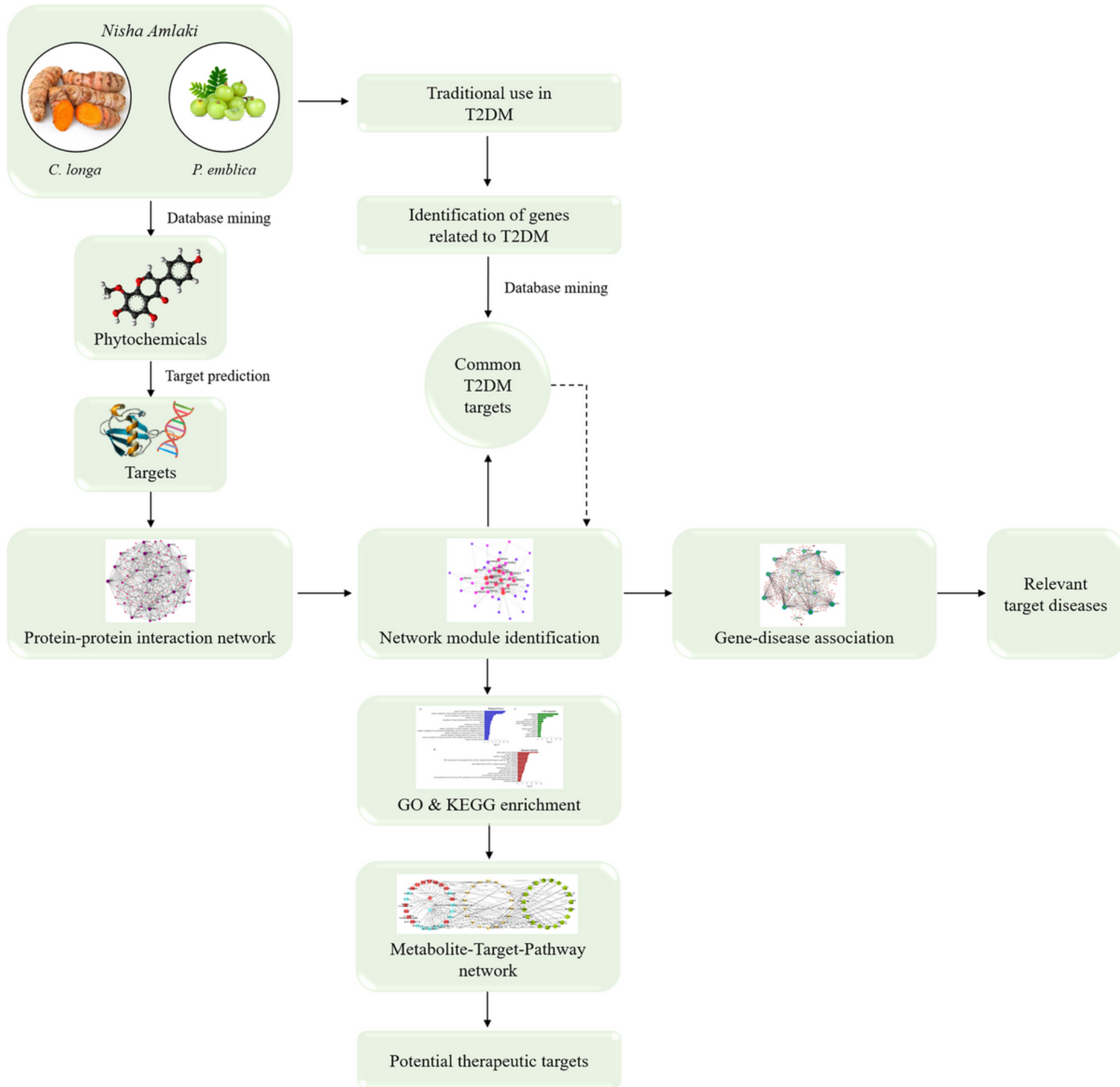

\section{Figure 1}

Workflow of network pharmacology-based approach for Nisha Amalaki 


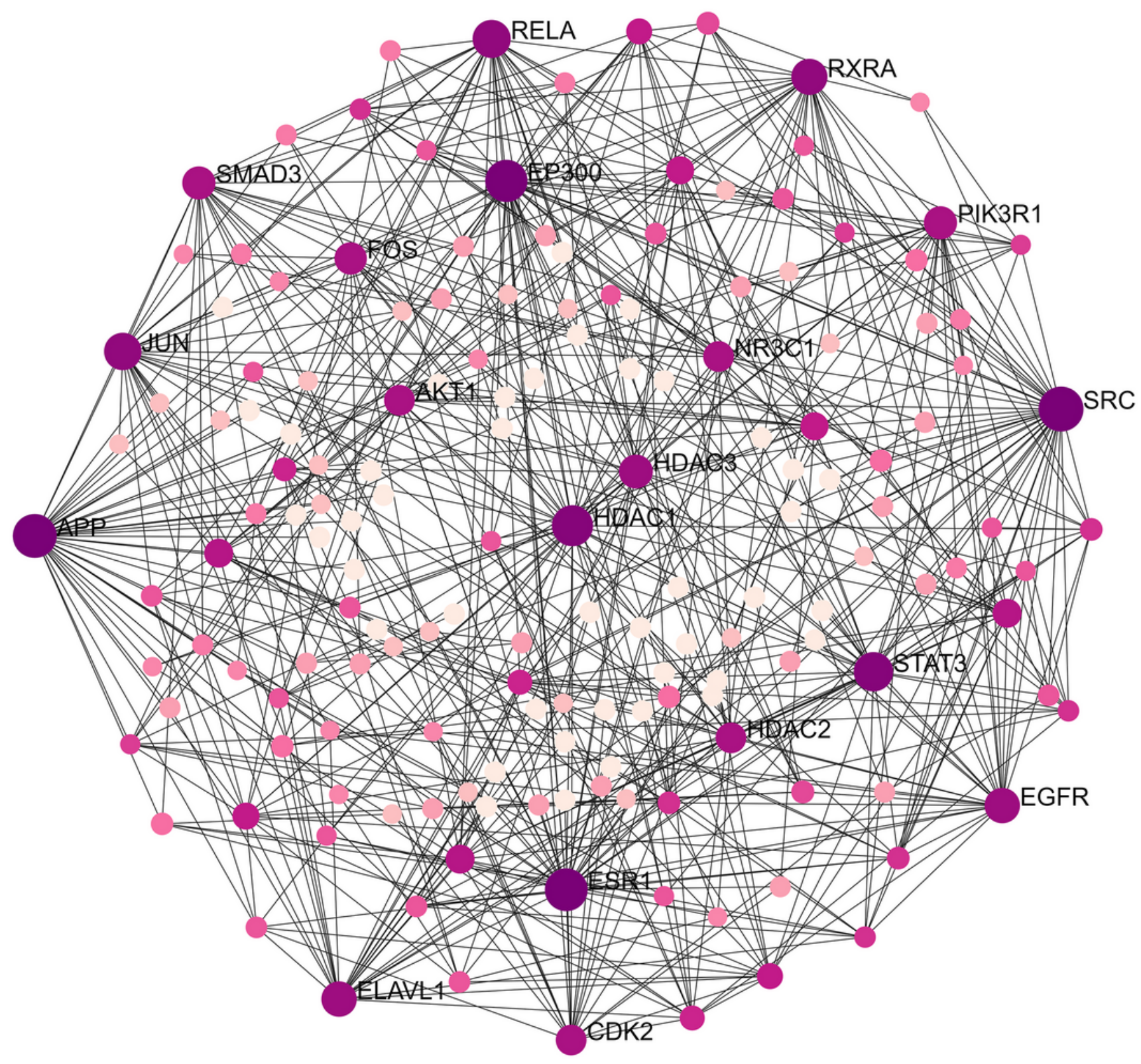

Figure 2

Protein-protein interaction network of Nisha Amalaki targets. The network was constructed using NetworkAnalyst 3.0. The node size and colour are related to degree of the target within the network. The gradient (colour: dark to light; size: large to small) represents high to low degree of the nodes within the network. 


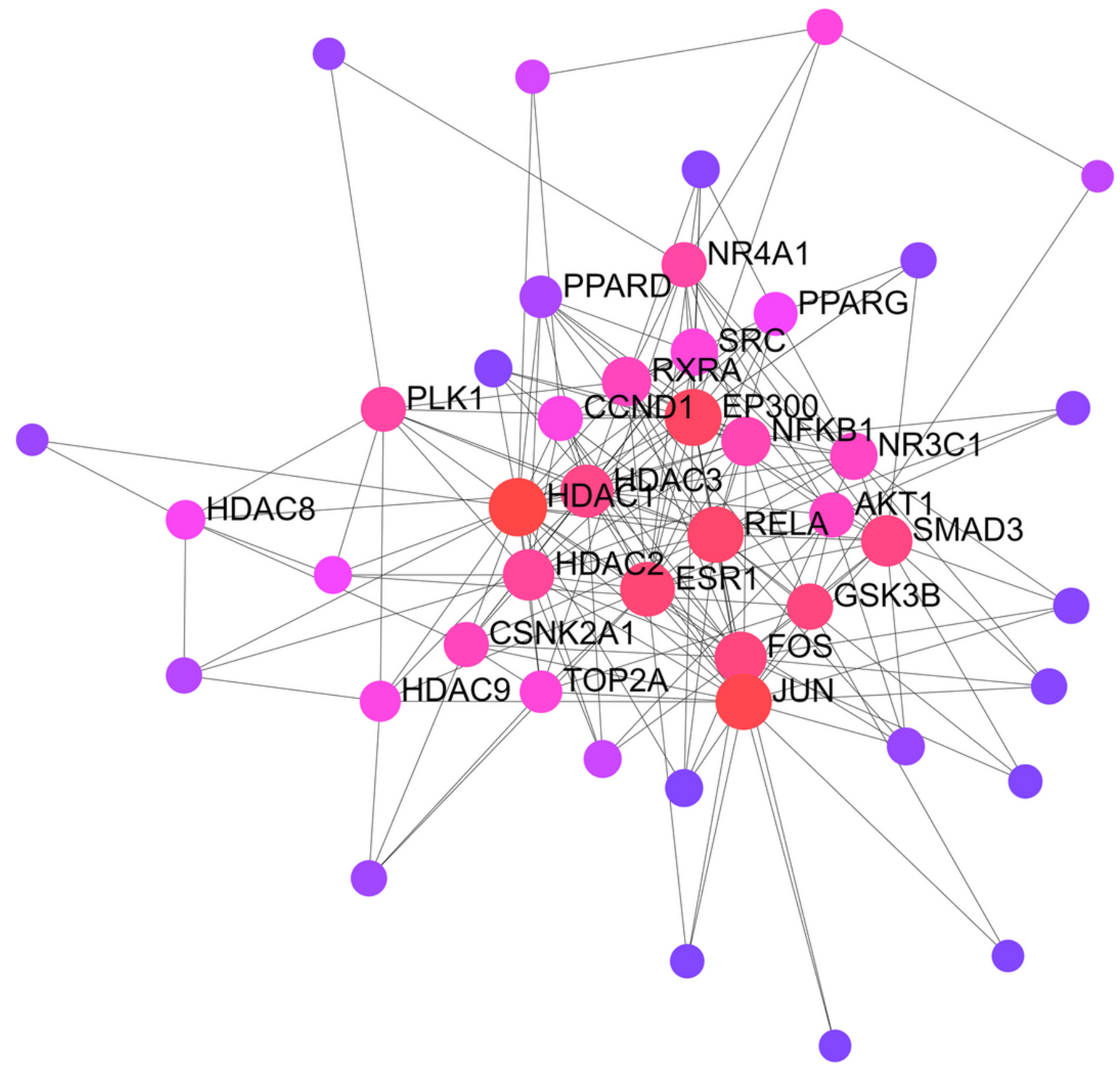

Figure 3

Protein-protein interaction network of Module 1. The network was constructed using NetworkAnalyst 3.0. The node size and colour are related to degree of the target within the network. The gradient (colour: red $\rightarrow$ pink $\rightarrow$ purple; size: large to small) represents high to low degree of the nodes within the network. 
(a) positive regulation of transcription from RNA polymerase II promoter positive regulation of transcription, DNA-templated histone $\mathrm{H} 3$ deacetylatio

regulation of signal transduction by $\mathrm{p} 53$ class mediato

$$
\text { aging }
$$

response to muscle stretch negative regulation of cell growth negative regulation of intrinsic apoptotic signaling pathway negative regulation of cysteine-type endopeptidase activity involved in apoptotic process negative regulation of transeription, DNA-templated extrinsic apoptotic signaling pathway in absence of ligand positive regulation of sequence-specific DNA binding transcription factor activity histone $\mathrm{H} 4$ deacetylation

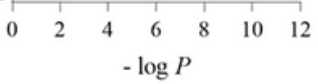

(c)

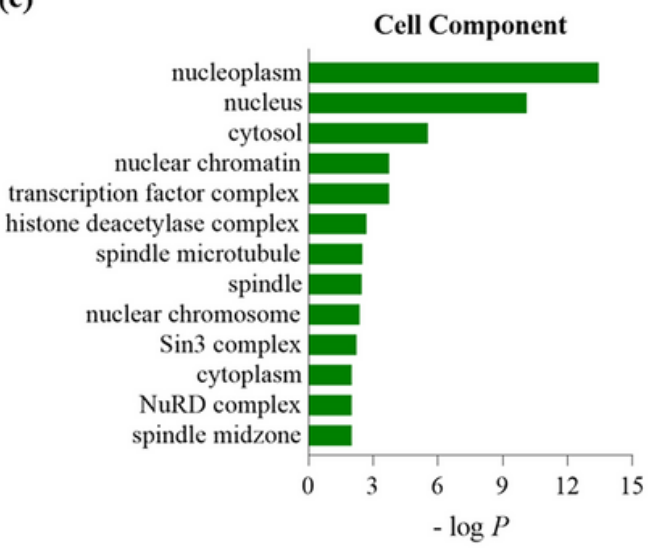

(b)

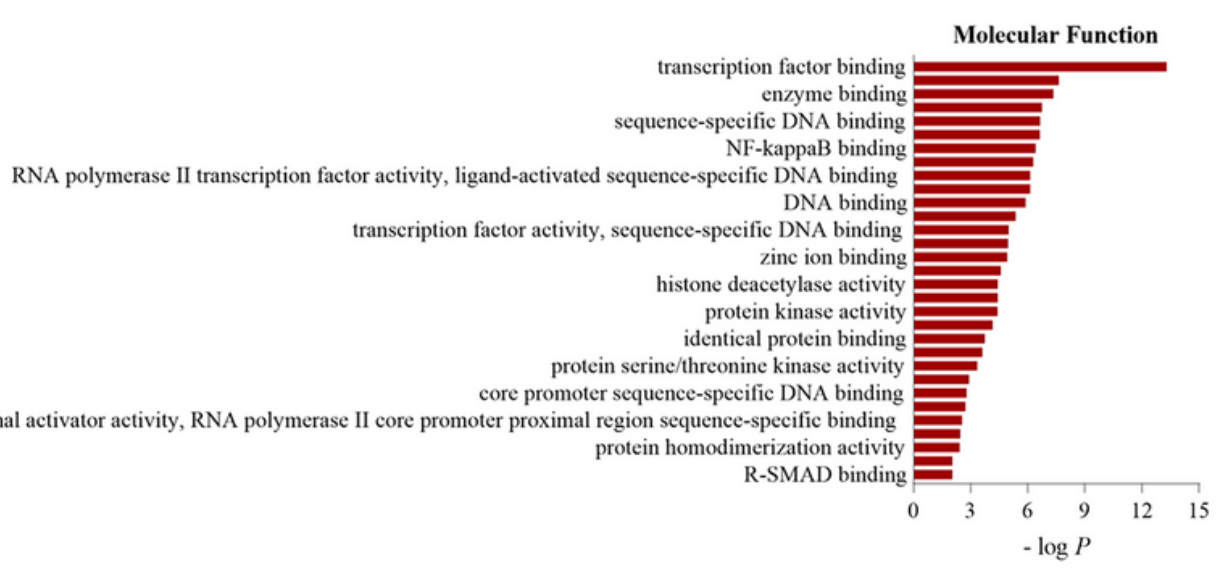

\section{Figure 4}

GO enrichment analysis of Nisha Amalaki targets. (a) Biological process (b) Molecular function (c) Cell component. The $\mathrm{x}$-axis denotes the $\mathrm{GO}$ term, whereas the $\mathrm{y}$-axis is the -log P-value. The $\mathrm{GO}$ terms with $\mathrm{P}$ $\leq .01$ (Benjamini-Hochberg) were selected. 


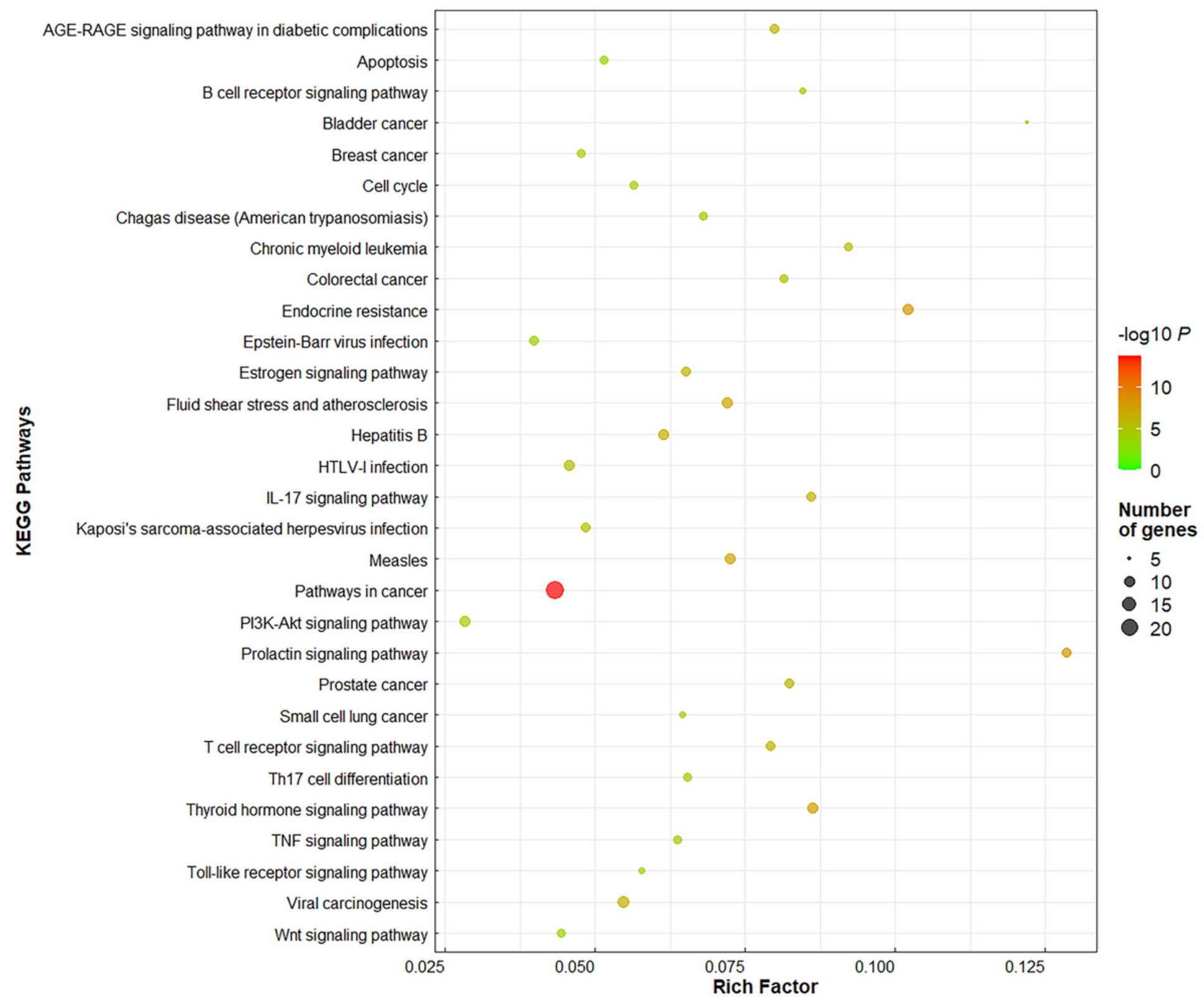

\section{Figure 5}

Scatter plot illustrating enriched KEGG pathways. Top 30 KEGG pathways are depicted in the figure. The rich factor was determined by dividing the number of genes enriched in a pathway by the total number of genes annotated in that pathway. The colour and size of the dots denote the range of the -log P-value and the number of genes in the shown pathways, respectively. The scatter plot was made using R software v4.0.3. 


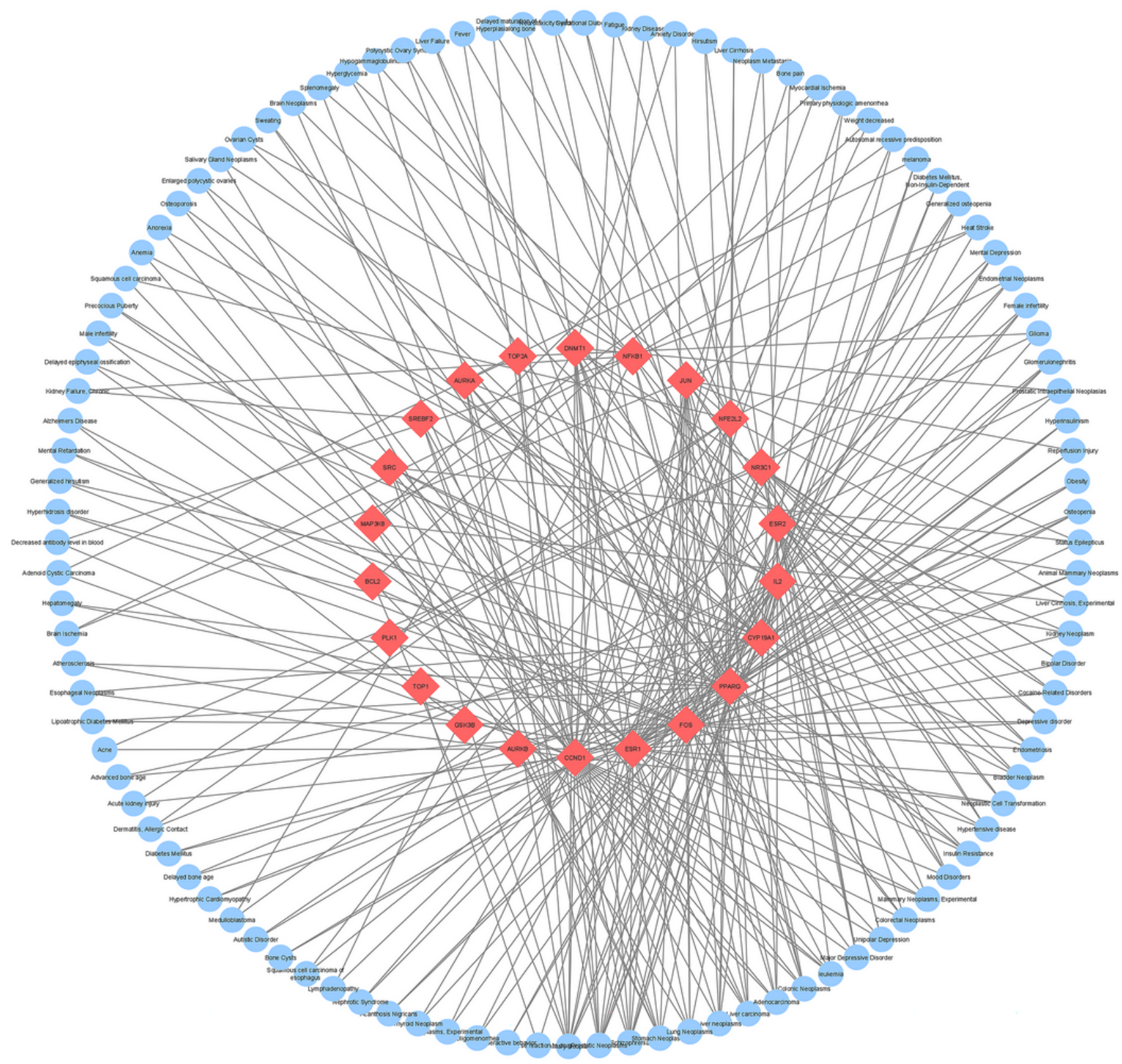

Figure 6

Gene-disease association network. The degree sorted network was constructed using Cytoscape v3.8.2. The red diamonds and blue circles represent the target genes of Nisha Amalaki in Module 1 and the significant diseases with betweenness $\geq 50$, respectively. Edges represent the interaction between genes and diseases. 


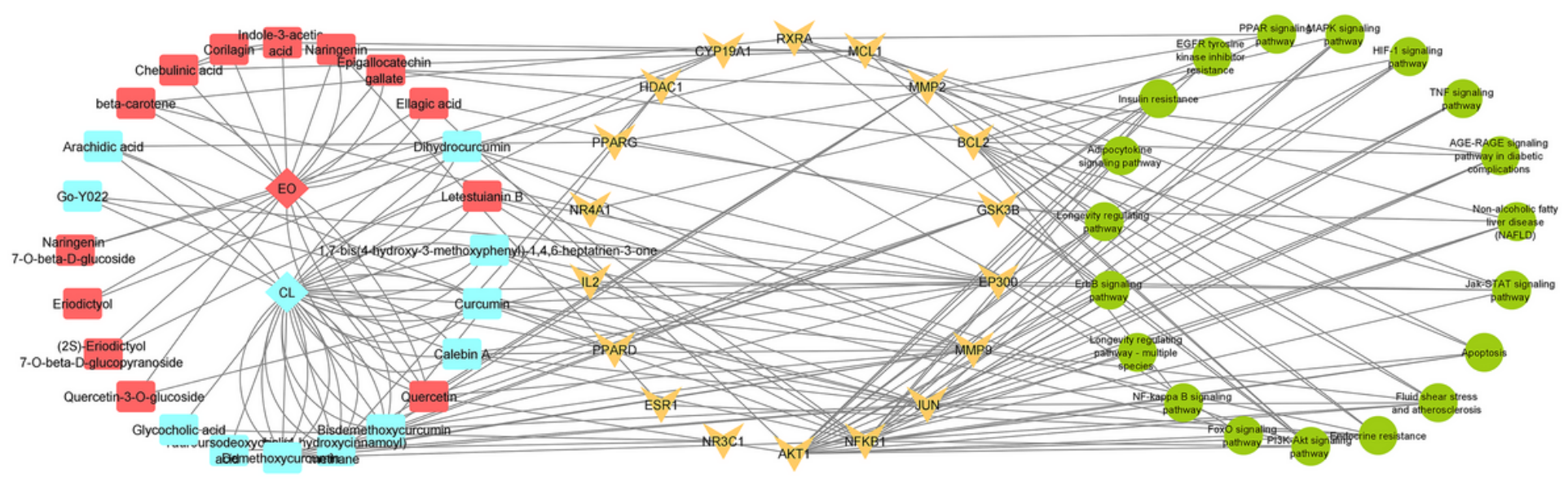

Figure 7

Metabolite-Target-Pathway interaction network related to T2DM. The degree sorted network was constructed using Cytoscape v3.8.2. The red and blue diamond represents the herbs CL: Curcuma longa; EO: Emblica officinalis. The red and blue rectangles depict the phytochemicals of EO and CL, respectively. The orange arrows and green circles denote the T2DM related target genes and pathways, respectively. Edges denote the interaction between metabolites, targets, and pathways.

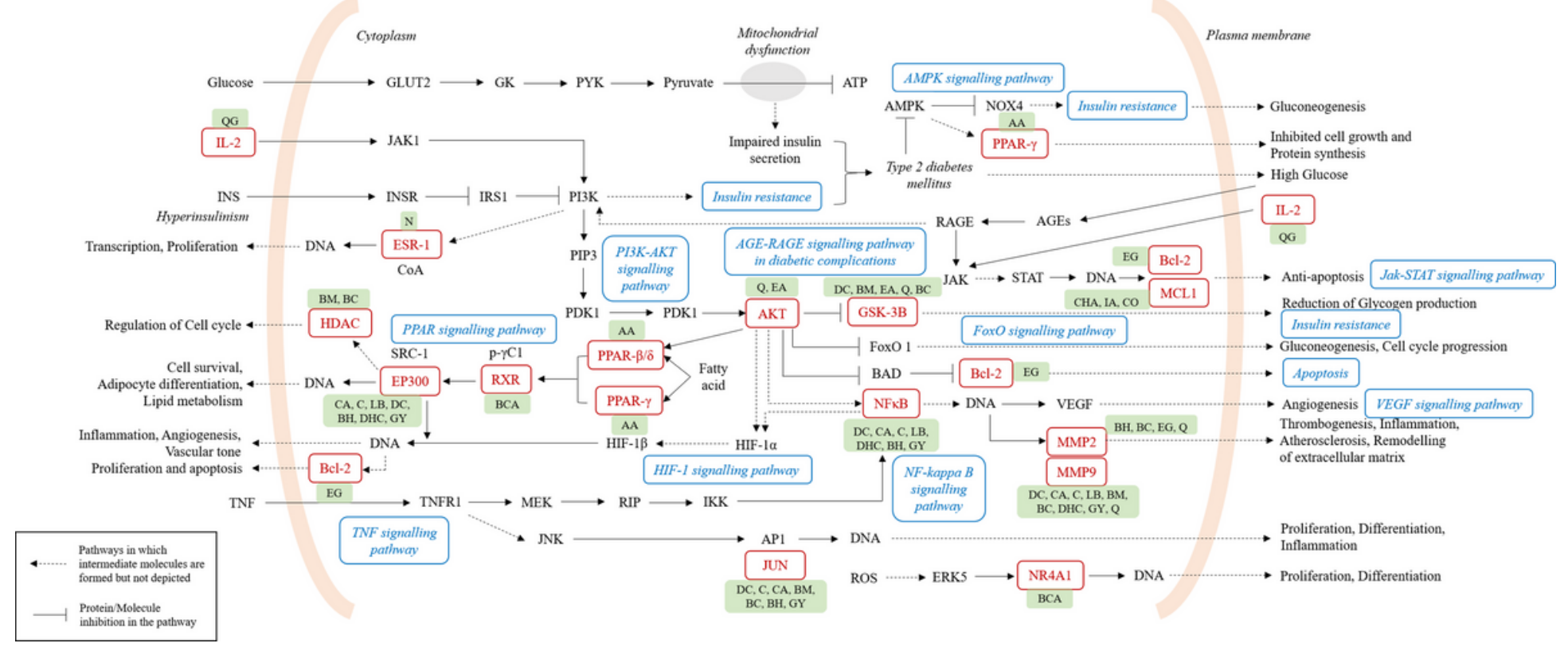

Figure 8

Target proteins of Nisha Amalaki and their distribution in the T2DM related pathways. The red boxes are potential target proteins of $\mathrm{C}$. longa and $\mathrm{E}$. officinalis, while the pathways in the blue box are related to T2DM. The green boxes represent the relevant phytochemicals of NA. Q, quercetin; EA, ellagic acid; AA, arachidic acid; QG, quercetin-3-0-glucoside; CA, calebin A; C, curcumin; BM, bis-(4-hydroxycinnamoyl) methane; DC, demethoxycurcumin; DHC, dihydrocurcumin; LB, letestuianin B; BCA, beta-carotene; GY, Go- 
Y022; BH, 1,7-bis(4-hydroxy-3-methoxyphenyl)-1,4,6-heptatrien-3-one; BC, bisdemethoxycurcumin; IA, indole-3-acetic acid; $\mathrm{CO}$, corilagin; $\mathrm{CHA}$, chebulinic acid.

\section{Supplementary Files}

This is a list of supplementary files associated with this preprint. Click to download.

- Supplementaryfile1.xlsx

- Supplementaryfile2.xlsx

- Supplementaryfile3.xlsx

- Supplementaryfile4.xlsx

- Supplementaryfile5.xlsx

- Supplementaryfile6.docx 